University of South Florida

DIGITAL COMMONS

Digital Commons @ University of

@ UNIVERSITY OF SOUTH FLORIDA

South Florida

$3-28-2012$

\title{
Low Level Exposure to Air Pollution and Risk of Adverse Birth Outcomes in Hillsborough County, Florida
}

\author{
Maria B. Mainolfi \\ University of South Florida, mmainolf@health.usf.edu
}

Follow this and additional works at: https://digitalcommons.usf.edu/etd

Part of the American Studies Commons, Environmental Health and Protection Commons, and the Medicine and Health Sciences Commons

\section{Scholar Commons Citation}

Mainolfi, Maria B., "Low Level Exposure to Air Pollution and Risk of Adverse Birth Outcomes in Hillsborough County, Florida" (2012). USF Tampa Graduate Theses and Dissertations.

https://digitalcommons.usf.edu/etd/4140

This Thesis is brought to you for free and open access by the USF Graduate Theses and Dissertations at Digital Commons @ University of South Florida. It has been accepted for inclusion in USF Tampa Graduate Theses and Dissertations by an authorized administrator of Digital Commons @ University of South Florida. For more information, please contact digitalcommons@usf.edu. 
Low Level Exposure to Air Pollution and Risk of Adverse Birth Outcomes in Hillsborough County, Florida

by

\author{
Maria B. Mainolfi \\ A thesis submitted in partial fulfillment \\ of the requirements of the degree of \\ Master of Science in Public Health \\ Department of Environmental and Occupational Health \\ College of Public Health \\ University of South Florida
}

Major Professor: Hamisu M. Salihu, M.D., Ph.D.

Alfred K. Mbah, Ph.D.

Thomas Truncale, D.O., M.S.P.H.

Date of Approval:

March 28, 2012

Key Words:

Carbon Monoxide, Particulate Matter, Particulate Pollutants, Nitrogen Dioxide, Ozone, Lead, Low Birth Weight, Small for Gestational Age, Preterm Birth

Copyright (C) 2012, Maria Mainolfi 


\section{ACKNOWLEDGMENTS}

This research project was supported in part by funding from the Sunshine Education and Research Center (ERC) at the University of South Florida (USF). The Sunshine ERC is supported by a training grant from the National Institute for Occupational Safety and Health (NIOSH) of the Centers for Disease Control and Prevention (CDC) (Award \#: T42-CCT412874). The content of this report are solely the responsibility of the author and do not necessarily represent the official views of the ERC, NIOSH, or USF.

I would like to thank my committee for their time, advice, and encouragement throughout the development and completion of my thesis. I would like to specifically extend my gratitude to Dr. Hamisu Salihu, without whom this research would not be possible. Dr. Salihu provided guidance and expertise on this area of study. I would also especially like to thank Dr. Mbah, whom helped with the statistical design and interpretation of the compiled data. It has been an honor working with and learning from this esteemed group of professors. 
TABLE OF CONTENTS

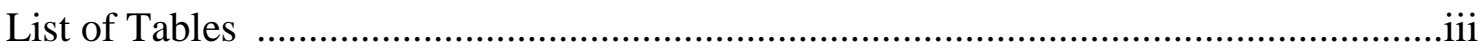

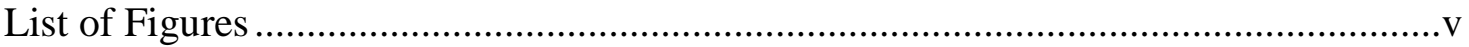

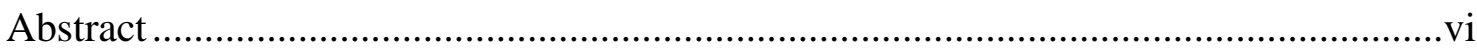

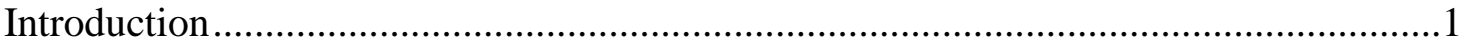

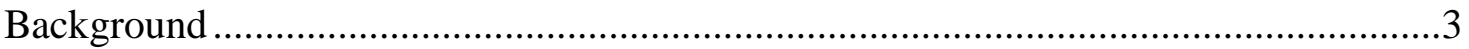

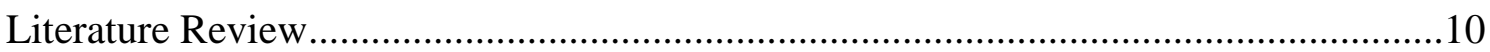

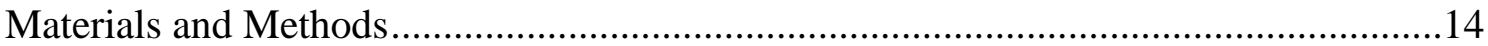

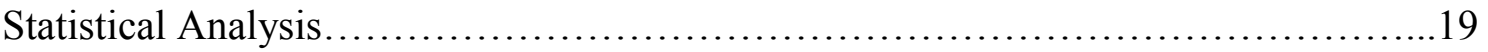

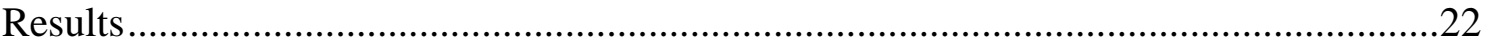

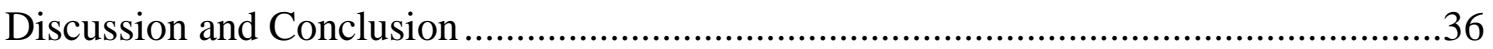

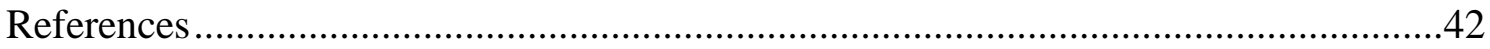

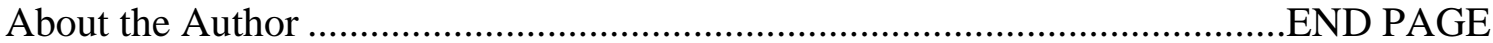




\section{LIST OF TABLES}

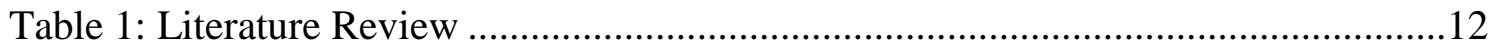

Table 2: Maternal demographic characteristics ....................................................23

Table 3: Demographic and pregnancy complications of women in the study ................24

Table 4: EPA National Air Pollution Standards compared to compared to pollutant levels

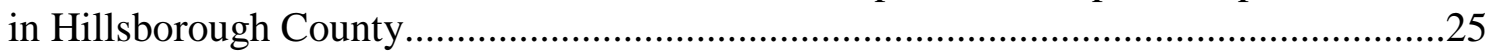

Table 5: National proportion of pregnancy complications compared to those in

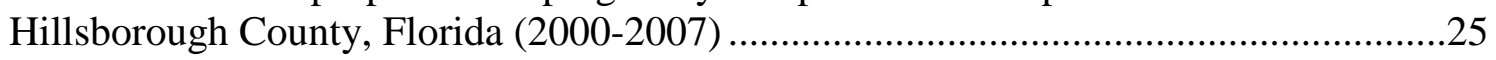

Table 6: National infant morbidity statistics compared to those in Hillsborough County,

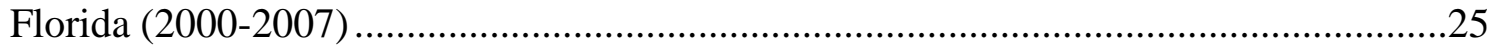

Table 7: Results of Exploratory Factor Analysis ..................................................26

Table 8: Parameter estimates from structural equation modeling ..............................26

Table 9: Quartile data odds ratios and 95\% confidence intervals compared across

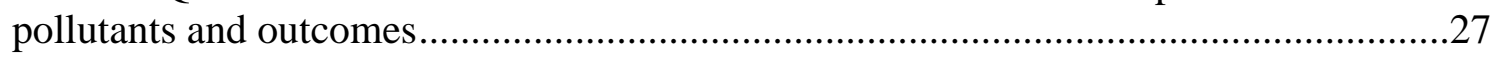

Table 10: Mantel-Haenszel Chi Square P-Values for Adjusted Quartile data

Table 11: Trimester data odds ratios and 95\% confidence intervals compared across pollutants and outcomes. 


\section{LIST OF FIGURES}

Figure 1: Ambient air CO in State of Florida compared to national standard over the past decade

Figure 2: Ambient air NO in State of Florida compared to national standard over the past decade

Figure 3: Ambient air Lead in State of Florida compared to national standard over the past decade.

Figure 4: Ambient air Ozone in State of Florida compared to national standard over the past decade ..................................................................................................

Figure 5: Ambient air $\mathrm{PM}_{10}$ in State of Florida compared to national standard over the

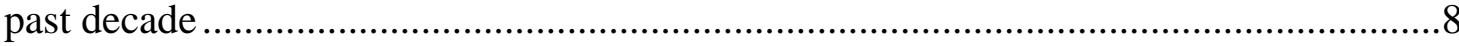

Figure 6: Path diagram composed of the measurement and structural model for the proposed analysis 


\begin{abstract}
In this retrospective cohort from 2002 through 2007, 104,003 singleton live births in Hillsborough County, Florida were analyzed to elucidate the relationship between fetoinfant morbidity outcomes and prenatal exposure to six criteria air pollutants. This study is based on three linked databases: The Florida Hospital Discharge database; The vital statistics records of singleton live births; Air Pollution meteorological data from the Environmental Protection Agency. There are six common air pollutants, particulate matter 2.5 (PM2.5), particulate matter 10 (PM10), ground-level ozone $\left(\mathrm{O}_{3}\right)$, carbon monoxide $(\mathrm{CO})$, nitrogen $(\mathrm{NOx})$, and lead $(\mathrm{Pb})$. These pollutants are harmful to human health and the environment. The primary outcomes of interest were low birth weight (LBW), preterm births, and small for gestational age (SGA). The intent of this project is to address these issues of air pollution effects and the methodology surrounding the study of air pollution.
\end{abstract}

Using modeling, exposure values of the six criteria air pollutants were assigned to mothers over their period of pregnancy. To address these methodological concerns, this study utilizes the structural equation modeling, quartile groupings with dose response, and trimester groupings to evaluate the relationship between air pollution and birth outcomes of pregnant residents.

Using structural equation modeling a significant B value of 0.35 indicated that exposure to the six criteria pollutant in pregnancy may have a significant relationship to 
all five birth outcomes if they are broken down into latent variables. Quartile data demonstrated that NOx seemed to have most significant associations with all outcomes with a dose response for SGA. $\mathrm{PM}_{10}$ and $\mathrm{PM}_{2.5}$ had some association to $\mathrm{LBW}$ and VLBW at high levels. $\mathrm{PM}_{10}$ demonstrated significance in the higher doses for SGA. However, the only dose response relationship that was demonstrated for $\mathrm{PM}_{10}$ and $\mathrm{PM}_{2.5}$ was in VLBW. $\mathrm{PM}_{10}$ also demonstrated a dose response with very preterm. If sub-divided into trimester data, $\mathrm{PM}_{10}$ demonstrated a significant relationship between exposures in all trimesters and LBW, VLBW, and SGA. $\mathrm{PM}_{2.5}$ demonstrated a significant relationship between exposures in all trimesters and VLBW. CO demonstrated a significant relationship in the $2^{\text {nd }}$ trimester for LBW as well as for SGA.

Mothers and their babies are a vulnerable population who are more susceptible to lower levels of pollution. These air pollutants can possibly have long-term effect on their children. Implantation of laws and regulations, warning system, or more strict EPA standards may be needed to adequately control the cost to our society. 


\section{INTRODUCTION}

As the evidence for global warming becomes all too apparent, the nation looks for alternative fuel and resources to reduce air pollution and disruption to the natural environment. Air pollution is common to all cities and exists in high concentrations in areas of heavy traffic or near industrial plants (Environmental Protection Agency [EPA, 2009],). Air pollutants not only cause global warming, but also have deleterious effects on human health. In response, the Environmental Protection Agency developed national standards under the Clean Air Act of 1970. In 1990, twenty years after the Clean Air Act was established, more than 200,000 premature deaths were prevented, and almost 700,000 cases of chronic bronchitis were avoided (Moore et al., 2007). Furthermore, total emissions of the six principal air pollutants have decreased by more than 41 percent (Moore et al., 2007). While these national standards were developed to minimize the effect of air pollutants on adults, little is known about the safe ranges of air pollutants for vulnerable populations, such as pregnant women and their children. This is worrisome, as current research suggests poor prenatal outcomes are associated with exposure to poor air quality (Ballester et al., 2010; Bremmer et al., 2004).

Due to the mounting evidence (as demonstrated in the Literature Review Section

of this thesis) of the vulnerability of children to air pollutants, there has been a growing interest in research focusing on the effects or potential impact of prenatal exposure. Clinical trials are rare in this population and unfeasible in many circumstances. Using an 
observational study design, researchers have examined the association between exposure to air pollution and a number of birth outcomes, including birth weight (Ballester et al., 2010; Gouveia et al., 2004), birth defects (Hansen et al., 2009; Ren et al., 2010), and post-neonatal infant mortality and morbidity (Suwanwaiphatthana et al., 2010; Woodruff et al., 1997). Unfortunately, these studies have produced inconsistent results, as detailed subsequently in the Literature Review Section of this thesis. The methodological issues seem to permeate most of these published results because of the challenges posed by the validity of modeling approaches. Current analyses that attempt to capture the association between exposure to these pollutants and birth outcomes depend on single multiple comparisons (Denmark, 2007). A problem with such an approach is that multiple testing is ignored and the final result may not be quite accurate (Denmark, 2007). Another concern with this one-to-one single multiple analyses is that it is assumed that all the responses reflect the same underlying variable, a notion that may be quite misleading in many instances (Denmark, 2007). Accordingly, we undertook this study to assess the impact of exposure to $\mathrm{PM}_{10}, \mathrm{PM}_{2.5}, \mathrm{CO}, \mathrm{NO}_{2}$, ozone, and lead on fetal morbidity outcomes using a more complex but accurate model that takes into account latent variables and multiple analyses. In addition, we further analyzed our data using gradation of exposures (quartiles) and trimester groupings. 


\section{BACKGROUND}

Insults to the embryo are of critical concern as any potentially harmful exposure at this stage can affect organogenesis. The developing fertilized egg from the time it implants in the uterus up to eight completed weeks of pregnancy is defined as the embryo. After this time until the end of pregnancy, the developing offspring is considered a fetus. The end of pregnancy is considered normal at 38 to 40 weeks. Exposure assessment, especially during pregnancy, is a major challenge in most pollution studies. Ideally, exposure per pollutant per person would be desirable. However, researchers have to rely on estimates using distances from residence to the monitors on a regional scale. Carbon monoxide (or $\mathrm{CO}$ ) is a common environmental pollutant and the EPA's health-based national air quality standard is $9 \mathrm{ppm}$ (parts per million). Air pollution due to $\mathrm{CO}$ gas comes principally from motor vehicle exhaust. The proximity to a home or work area to traffic can significantly alter the exposure (EPA, 2009). Health problems associated with carbon monoxide include reduction of oxygen delivery to body organs and tissues. At high levels, $\mathrm{CO}$ is associated with visual impairment, reduced work capacity, impaired dexterity, poor learning ability, and difficulty in performing complex tasks. Figure 1 shows the yearly ambient air CO as captured in the State of Florida compared to national standard over the past decade.(retrieved from www.epa.gov) 
CO Air Quality, 1990 - 2009

(Based on Annual 2nd Maximum 8-hour Average)

Tampa-St. Petersburg-Clearwater,FL

SITE $=121030018$ POC $=1$

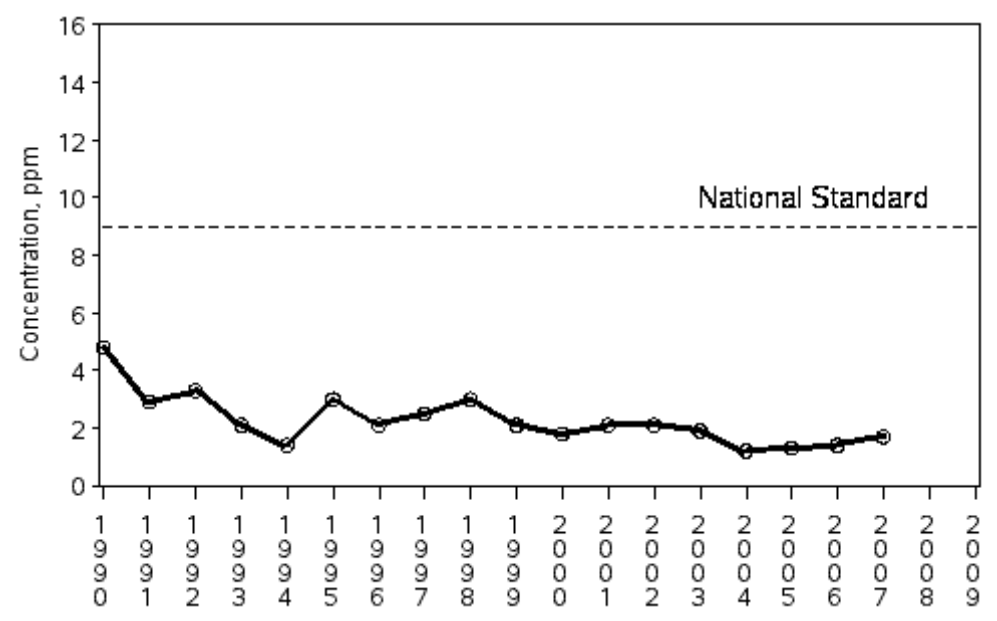

Figure 1: Ambient air $\mathrm{CO}$ in State of Florida compared to national standard over the past decade (EPA, 2009)

Nitrogen dioxide (or $\mathrm{NO}_{2}$ ) is one of a group of highly reactive gasses known as "oxides of nitrogen" or "nitrogen oxides (NOx)." The EPA's health-based national air quality standard is $0.053 \mathrm{ppm}$ (EPA, 2009). Air pollution due to NOx gas comes principally from motor vehicle exhaust (EPA, 2009). The proximity to a home or work area to traffic can significantly alter the exposure. It is a strong oxidizing agent that reacts with oxygen to form a highly corrosive nitric acid, as well as toxic organic nitrates, and contributes to smog production (EPA, 2009). Health problems associated with NOx include lung irritation and susceptibility to infections, such as influenza (Goings et al., 1989). In Florida, despite overall downward trend since 1986, it has only been by a marginal percentage 6\% between 1986-1995 (Figure 2) (EPA, 2009). 


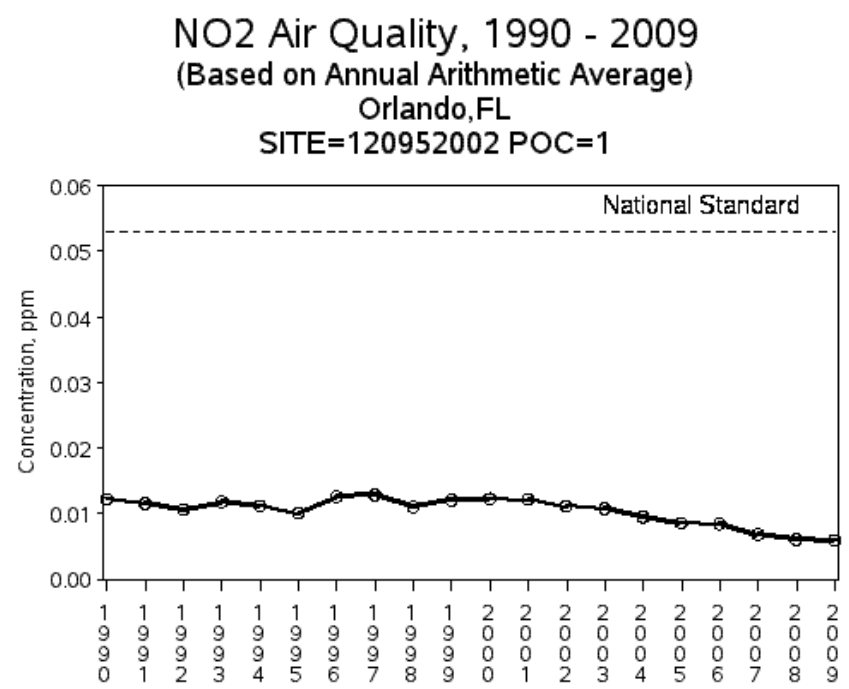

Figure 2: Ambient air NO in State of Florida compared to national standard over the past decade (EPA, 2009)

Lead has been used for centuries as a pesticide, in making pottery and piping, as an additive for gasoline, paint and even in food. Lead is widely dispersed and can be found in virtually all environment and animal tissue including the most remote locations of Antarctica (EPA 2009).EPA's health-based national air quality standard is 1.5 micrograms/m3. Air pollution generally comes from smelt, battery plants, and lead paint. Health problems associated with lead inhalation include accumulation in the kidneys, liver, and nervous system, and can cause anemia, kidney disease, reproductive disorders, and neurologic impairment, such as seizures, mental retardation, and behavioral disorders (EPA, 2009). At low doses in children and fetuses, lead exposure is associated with nervous system damage and slowed growth (EPA, 2009). In Florida, there is a steady state above the national standard (Figure 3) (EPA, 2009). 


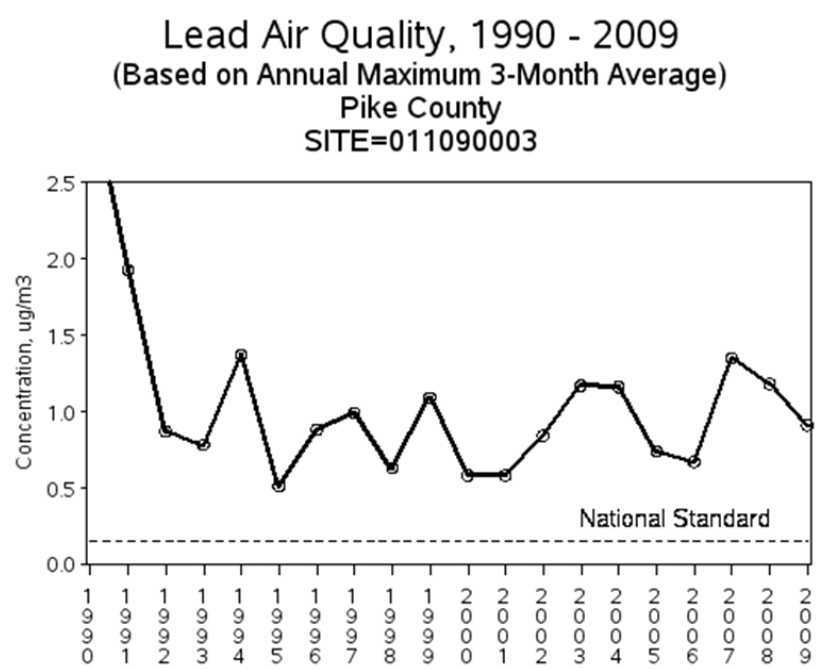

Figure 3: Ambient air Lead in State of Florida compared to national standard over the past decade (EPA, 2009)

Ozone is a naturally occurring gas and its levels have increased due mainly to man-made contributions. Ozone can drastically affect the progression of global warming. The EPA's health-based national air quality standard (the 3-year average of the fourthhighest daily maximum 8-hour average ozone concentration measured at each monitor within an area over each year) must not exceed 0.075 ppm (EPA, 2009). Ground-level ozone is not emitted directly into the air, but is created by chemical reactions between oxides of nitrogen (NOx) and volatile organic compounds (VOC) in the presence of sunlight (EPA, 2009). Emissions from industrial facilities and electric utilities, motor vehicle exhaust, gasoline vapors, and chemical solvents are some of the major sources of NOx and VOC (EPA, 2009). Health problems associated with ozone include chest pain, coughing, throat irritation, and congestion. It can worsen bronchitis, emphysema, and asthma. Ground-level ozone also can reduce lung function and inflame the linings of the lungs (EPA, 2009). Repeated exposure may permanently scar lung tissue. Average ozone levels declined in the 1980s, leveled off in the 1990s, and showed a notable decline after 2002 (Figure 4) (EPA, 2009). 


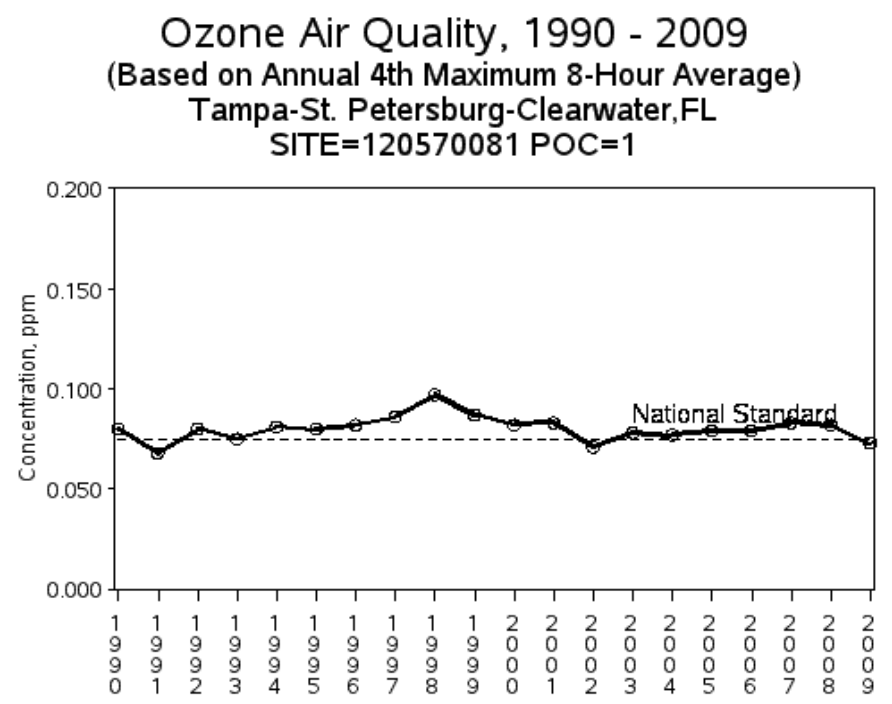

Figure 4: Ambient air Ozone in State of Florida compared to national standard over the past decade (EPA, 2009)

Particulate matter, also known as particle pollution or PM, is a complex mixture of extremely small particles and liquid droplets. The two types of particulate matter that are of health concern are: (1) $\mathrm{PM}_{10}$, which are larger than 2.5 micrometers and smaller than 10 micrometers in diameter and (2) $\mathrm{PM}_{2.5}$, which are fine particles 2.5 micrometers in diameter and smaller. The health effects occur because $\mathrm{PM}_{10}$ is readily inhalable, and, because of their size, they are not filtered and penetrate deeply into the body and cause cardiovascular and respiratory disorder (EPA, 2009). Because the particles originate from a variety of mobile and stationary sources (diesel trucks, woodstoves, power plants, etc.), their chemical and physical compositions vary widely (EPA, 2009) Particulate matter can be directly emitted or can be formed in the atmosphere when gaseous pollutants such as $\mathrm{SO}_{2}$ and NOx react to form fine particles (EPA, 2009). Figure 5 shows temporal trends in the levels of $\mathrm{PM}_{10}$ in Florida. The EPA did not report trends for $\mathrm{PM}_{2.5}$. 


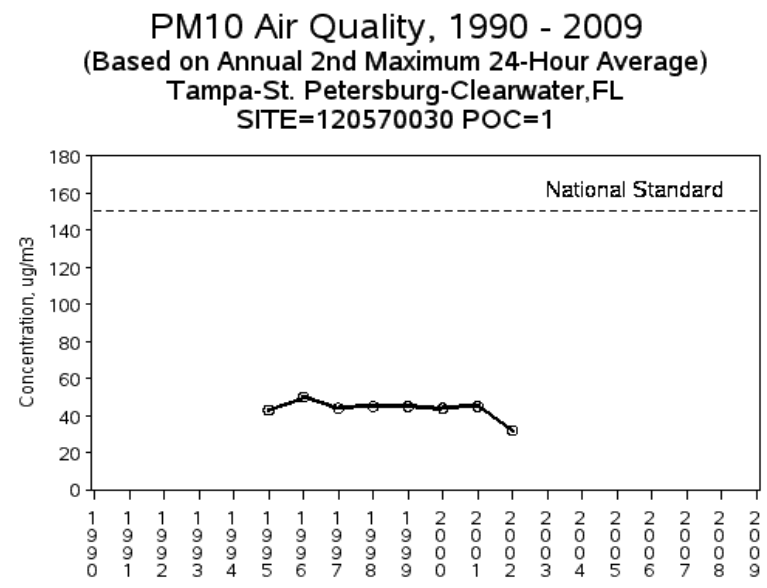

Figure 5: Ambient air PM 10 in State of Florida compared to national standard over the past decade (EPA, 2009)

The consequences of exposure examined in this study include preterm birth (PTB), small for gestational age (SGA), and low birth weight (LBW). PTB refers to delivery at less than 37 weeks gestation, while birth at less than 32 weeks is considered very preterm, and extremely preterm is defined as birth before 28 gestational weeks (WHO, 2004). When an infant is born preterm, internal organs are not mature enough to allow for normal postnatal survival. Preterm babies are at greater risk for short and long term complications, including disabilities, growth, and development problems. SGA babies are defined as those whose birth weight, length, or head circumference fall below the $10^{\text {th }}$ percentile for that gestational age (Alexander et al., 1998). Not all fetuses who are SGA are pathologically growth restricted; some are considered to be constitutionally small (Maisonet et al., 2004). LBW is defined as the weight at birth of less than 2,500 grams, while very low birth weight is less than 1,500 grams. LBW is either the result of preterm birth or restricted fetal growth. LBW is also an important predictor of newborn 
health and survival and is associated with elevated risk for infant and childhood mortality (WHO, 2004).

Of note, some studies indicate that prenatal hazards that restrict fetal growth may be associated with small but measurable delays in motor and social development through childhood and reduced cognitive development (Bacharach \& Baumeister, 1998; Hack et al., 1991; Hediger et al., 2002;. An association between birth size and future development of diseases during adulthood, such as type 2 diabetes and coronary artery disease, has also been demonstrated (Godfrey \& Barker, 2001; Phillips, 2000). It is believed that these associations arise from "early programming," a theory that specifies that the changes in structure and function caused by environmental factors during critical and vulnerable periods of early development persist through adult life. 


\section{LITERATURE REVIEW}

Results regarding the relationship between air pollution and birth weight are inconclusive, with some studies identifying associations where others did not, and the suite of adverse pollutants and exposure periods differing by study. For instance, higher levels of carbon monoxide were associated with low birth weight in southern California, São Paulo, Brazil, Sydney, Australia, and Seoul, South Korea (Gouveia et al., 2004; Ha et al., 2001; Maisonet et al., 2001; Mannes et al., 2005; Ritz et al., 2000; Salam et al., 2005). However, no association was identified in studies reported from the Czech Republic, Taiwan, Nevada, and California (Bobak et al. 2000; Parker et al., 2005).

Particulate matter $(\mathrm{PM})$ with an aerodynamic diameter $<10 \mu \mathrm{m}\left(\mathrm{PM}_{10}\right)$ was linked with low birth weight in São Paulo, Southern California, Poland, Beijing, China, and Taiwan (Dejmek et al., 1999; Gouveia et al., 2004; Ha et al., 2001; Jedrychowski et al., 2004; Wang et al., 1998). However, there was no indication of a positive association between prenatal exposures to $\mathrm{PM}_{10}$ and LBW in the Northeast United Sates (Maisonet et al., 2001). One noteworthy study by Salihu et.al 2011 using the same data set demonstrated that women exposed (values above median) to PM 10 and PM 2.5 had an increased rate of low birth weight, very low birth weight and preterm birth. Black women had the greatest odds for all morbidity outcomes, with the greatest relationship to very low birth weight. (Salihu et. al. 2011) 
Studies on the effect of ozone were less in number and were not well defined for the outcomes of interest. One study in Australia demonstrated an association with increased risk of aortic artery and valve defects (Hansen et Al., 2005). Another study that looked at ozone, as well as $\mathrm{CO}$ and $\mathrm{PM}_{10}$, found that ozone exposure during the second and third trimesters and $\mathrm{CO}$ exposure in the first trimester were associated with reduced birth weight (Salam et al., 2005).

A study conducted in Spain found that $\mathrm{NO}_{2}$ exposure at $>40 \mu \mathrm{g} / \mathrm{m}^{3}$ during the first trimester was associated with reduced birth length, birth weight, and birth height (Ballester et al., 2007). In studies conducted by Bobak et al (2000) and Landgren et al (1996), NOx in all trimesters demonstrated a significant association with preterm delivery but not with LBW.

Lead as an air pollutant has been mostly ignored due to the abundance of research on its effects on children. Most studies that investigate air pollution omit lead from the reposted pollutants. Further information is available in Table 1, which provides an overview of the literature review. 
Table 1: Literature Review

\begin{tabular}{|c|c|c|c|c|c|}
\hline $\begin{array}{c}\text { Study } \\
\text { (Authors) }\end{array}$ & $\begin{array}{c}\text { Setting } \\
\& \\
\text { Popula } \\
\text { tion } \\
\text { Size } \\
\end{array}$ & Pollutants & $\begin{array}{c}\text { Publication } \\
\text { Date }\end{array}$ & Data Source & Results \\
\hline $\begin{array}{l}\text { Ambient } \\
\text { Air } \\
\text { Pollution } \\
\text { and Birth } \\
\text { Defects in } \\
\text { Brisbane } \\
\text { Australia } \\
\text { (Hansen, et } \\
\text { al.) }\end{array}$ & $\begin{array}{l}\text { Australi } \\
\text { a } \\
(\mathrm{N}=150 \\
, 308 \\
\text { Births })\end{array}$ & $\begin{array}{l}\text { Ozone, } \\
\mathrm{SO}_{2}, \mathrm{NO}_{2} \\
\mathrm{CO}, \text { and } \\
\mathrm{PM}_{10}\end{array}$ & $1998-2004$ & $\begin{array}{l}\text { Queensland } \\
\text { Health } \\
\text { Perinatal Data } \\
\text { Collection Unit }\end{array}$ & $\begin{array}{l}\mathrm{O}_{3} \text { was associated with an increase } \\
\text { of aortic artery and valve defects. } \\
\text { So } 2 \text { was associated with cleft lip. }\end{array}$ \\
\hline $\begin{array}{l}\text { Birth } \\
\text { Outcomes } \\
\text { and } \\
\text { Prenatal } \\
\text { Exposure } \\
\text { to Ozone, } \\
\text { Carbon } \\
\text { Monoxide, } \\
\text { and } \\
\text { Particulate } \\
\text { Matter: } \\
\text { Results } \\
\text { from the } \\
\text { Children's } \\
\text { Health } \\
\text { Study } \\
\text { (Salam, et }\end{array}$ & $\begin{array}{l}\text { Califor } \\
\text { nia } \\
(\mathrm{N}= \\
6,259 \\
\text { Births })\end{array}$ & $\begin{array}{l}\text { Ozone, } \\
\mathrm{CO}, \text { and } \\
\mathrm{PM}_{10}\end{array}$ & $1975-1987$ & $\begin{array}{l}\text { Children's } \\
\text { Health Study }\end{array}$ & $\begin{array}{l}\text { Ozone during the second and third } \\
\text { trimesters and CO exposure in the } \\
\text { first trimester were associated with } \\
\text { reduced birth weight. }\end{array}$ \\
\hline
\end{tabular}




\begin{tabular}{|c|c|c|c|c|c|}
\hline al.) & & & & & \\
\hline $\begin{array}{l}\text { Association } \\
\text { between } \\
\text { Ambient } \\
\text { Air } \\
\text { Pollution } \\
\text { and Birth } \\
\text { Weight in } \\
\text { Sao Paulo, } \\
\text { Brazil } \\
\text { (Gouveia et } \\
\text { al.) }\end{array}$ & $\begin{array}{l}\text { Brazil } \\
(\mathrm{N}=196 \\
, 978 \\
\text { Births })\end{array}$ & $\begin{array}{l}\text { Ozone, } \\
\mathrm{CO}, \mathrm{PM}_{10} \\
\mathrm{NO}_{2} \text {, and } \\
\mathrm{SO}_{2}\end{array}$ & 1997 & $\begin{array}{l}\text { Ministry of } \\
\text { Health in } \\
\text { Brazil }\end{array}$ & $\begin{array}{l}\text { CO exposure in the first semester } \\
\text { was associated with reduction of } \\
\text { birth weight by } 23 \mathrm{~g} \text {. }\end{array}$ \\
\hline $\begin{array}{l}\text { Effect of } \\
\text { Air } \\
\text { Pollution } \\
\text { on Preterm } \\
\text { Birth } \\
\text { Among } \\
\text { Children } \\
\text { Born in } \\
\text { Southern } \\
\text { California } \\
\text { Between } \\
\text { 1989 and } \\
\text { 1993 (Ritz } \\
\text { et al.) }\end{array}$ & $\begin{array}{l}\text { Souther } \\
\mathrm{n} \\
\text { Califor } \\
\text { nia } \\
(\mathrm{N}=97 \text {, } \\
518 \\
\text { neonate } \\
\text { s) }\end{array}$ & $\begin{array}{l}\mathrm{CO}, \mathrm{NO}_{2}, \\
\text { ozone, and } \\
\mathrm{PM}_{10}\end{array}$ & 2000 & $\begin{array}{l}\text { California } \\
\text { Department of } \\
\text { Health } \\
\text { Services }\end{array}$ & $\begin{array}{l}16-20 \% \text { increase in preterm birth } \\
\text { per } 50-\mu \mathrm{g} \text { increase in ambient } \\
\mathrm{PM}_{10} \text { levels averaged over } 10-6 \\
\text { weeks before birth. } \mathrm{PM}_{10} \text { effects } \\
\text { showed no regional pattern. } \mathrm{CO} \\
\text { exposure } 6 \text { weeks only for inland }\end{array}$ \\
\hline $\begin{array}{l}\text { Estimated } \\
\text { Risk for } \\
\text { Altered } \\
\text { Fetal } \\
\text { Growth } \\
\text { Resulting } \\
\text { from }\end{array}$ & Poland & $\mathrm{PM}_{2.5}$ & 2004 & N/A & $\begin{array}{l}\text { Predicted reduction in birth weight } \\
\text { at an increase of exposure from } 10 \\
\text { to } 50 \mu \mathrm{g} / \mathrm{m}^{3} \text { was } 140.3 \mathrm{~g} \text {. }\end{array}$ \\
\hline
\end{tabular}




\begin{tabular}{|c|c|c|c|c|c|}
\hline $\begin{array}{l}\text { Exposure } \\
\text { to Fine } \\
\text { Particles } \\
\text { during } \\
\text { Pregnancy: } \\
\text { An } \\
\text { Epidemiolo } \\
\text { gic } \\
\text { Prospective } \\
\text { Cohort } \\
\text { Study in } \\
\text { Poland } \\
\text { (Jedrychow } \\
\text { ski et al.) } \\
\end{array}$ & & & & & \\
\hline $\begin{array}{l}\text { Air } \\
\text { pollution } \\
\text { exposure } \\
\text { during } \\
\text { pregnancy } \\
\text { and } \\
\text { reduced } \\
\text { birth size: a } \\
\text { prospective } \\
\text { birth cohort } \\
\text { study in } \\
\text { Valencia, } \\
\text { Spain } \\
\text { (Ballester } \\
\text { et al.) } \\
\end{array}$ & $\begin{array}{l}\text { Valenci } \\
\text { a, Spain } \\
\text { (N=785 } \\
\text { Births) }\end{array}$ & $\mathrm{NO}_{2}$ & 2010 & $\begin{array}{l}\text { Data from the } \\
\text { INMA cohort } \\
\text { in Valencia, } \\
\text { Spain }\end{array}$ & $\begin{array}{l}\mathrm{NO}_{2} \text { exposure }>40 \mu \mathrm{g} / \mathrm{m}^{3} \text { during } \\
\text { the first trimester was associated } \\
\text { with a change in birth length of - } \\
0.27 \mathrm{~cm} \text { and with a change in birth } \\
\text { weight of }-40.3 \text { grams,. And } \\
\text { change in birth height. }\end{array}$ \\
\hline $\begin{array}{l}\text { Association } \\
\text { between air } \\
\text { pollution } \\
\text { and low }\end{array}$ & $\begin{array}{l}\text { Beijing, } \\
\text { China } \\
(\mathrm{N}=74, \\
671\end{array}$ & $\begin{array}{l}\text { Total } \\
\text { suspended } \\
\text { particles } \\
\text { and } \mathrm{SO}_{2}\end{array}$ & 1997 & $\begin{array}{l}\text { 1988-1991 } \\
\text { Beijing Birth } \\
\text { Registry }\end{array}$ & $\begin{array}{l}\text { Significant exposure-response } \\
\text { relationship between maternal } \\
\text { exposure to } \mathrm{SO}_{2} \text { and total } \\
\text { suspended particles during the }\end{array}$ \\
\hline
\end{tabular}




\begin{tabular}{|c|c|c|c|c|c|}
\hline $\begin{array}{l}\text { birth } \\
\text { weight: a } \\
\text { community } \\
\text {-based } \\
\text { study } \\
\text { (Wang et } \\
\text { al.) }\end{array}$ & Births) & & & & $\begin{array}{l}\text { third trimester of pregnancy and } \\
\text { infant birth weight. }\end{array}$ \\
\hline $\begin{array}{l}\text { Relation } \\
\text { between } \\
\text { ambient air } \\
\text { pollution } \\
\text { and low } \\
\text { birth } \\
\text { weight in } \\
\text { the } \\
\text { Northeaster } \\
\text { n United } \\
\text { States } \\
\text { (Maisonet } \\
\text { et al.) }\end{array}$ & $\begin{array}{l}\text { Northea } \\
\text { st US }\end{array}$ & $\begin{array}{l}\mathrm{CO}, \mathrm{PM}_{10} \\
\text { and } \mathrm{SO}_{2}\end{array}$ & 2001 & N/A & $\begin{array}{l}\mathrm{CO} \text { and } \mathrm{SO}_{2} \text { increased the risk for } \\
\text { term } \mathrm{LBW} \text {. There was no } \\
\text { indication of a positive association } \\
\text { between prenatal exposures to } \\
\mathrm{PM}_{10} \text { and LBW. }\end{array}$ \\
\hline $\begin{array}{l}\text { Fetal } \\
\text { growth and } \\
\text { maternal } \\
\text { exposure to } \\
\text { particulate } \\
\text { matter } \\
\text { during } \\
\text { pregnancy } \\
\text { (Dejmek et } \\
\text { al.) }\end{array}$ & $\begin{array}{l}\text { Teplice } \\
\text { District } \\
\text {, Czech } \\
\text { Republi } \\
\text { c }\end{array}$ & $\begin{array}{l}\text { Total } \\
\text { suspended } \\
\text { particles } \\
\text { and } \mathrm{SO}_{2}\end{array}$ & 1999 & $\begin{array}{l}\text { All singleton } \\
\text { full-term births } \\
\text { of European } \\
\text { origin over a 2- } \\
\text { year period in } \\
\text { the Teplice } \\
\text { District }\end{array}$ & $\begin{array}{l}\text { Adjusted ORs for IUGR related to } \\
\text { ambient PM10 levels in the first } \\
\text { gestational month increased along } \\
\text { the concentration intervals. No } \\
\text { other associations of IUGR risk } \\
\text { with particulate matter were found. }\end{array}$ \\
\hline
\end{tabular}




\section{METHODS AND MATERIALS}

The study population includes all live births in Hillsborough County, Florida during the period from 2000 to 2007. The linked de-identified hospital discharge and vital statistics birth data for Hillsborough County had a total of 104,003 singleton live births for the study. Additionally, publicly available air pollution and meteorological data from the EPA (USA Air Quality System, http://www.epa.gov) were used for analysis. The pollutants were monitored at 14 different stationary monitoring stations located throughout Hillsborough County. Recordings from 2000 to 2007 were obtained and the 24-hour daily maximum concentrations were computed to assess exposure to air pollutants. The pollution data also included latitudes and longitudes, which were converted to zip codes manually using the Hillsborough Environmental Pollution Commission website. For maternal exposure assessment, the following steps were taken to assign air pollution exposures to each mother. We computed the Euclidian distances between the centroid of the mother's residential zip code during pregnancy and the centroid of each zip code of the 14 monitoring stations. Since there were 14 monitoring sites and 97 residential zip codes in Hillsborough County, we had a matrix with entries of $97 \times 14$ distances (each residential zip code had 14 computed distances). The monitoring site with the minimum distance was assigned to each residential zip code since this will be the monitor with the greatest exposure for the mothers within that zip code. If there were missing data from the closest site for a particular day of gestation, then the reading 
was taken from the next closest site without missing data. If the daily readings were missing across all sites, then the daily exposure estimate was left as missing (Hansen et al., 2009).

The main outcomes of interest included low birth weight (LBW: $<2,500$ grams), very low birth weight (VLBW: <1,500 grams), preterm birth (PTB: <37 weeks), very preterm birth (VPTB: <33 weeks), and small for gestational age (SGA). We defined SGA as less than the 10th percentile of birth weight for a given gestational age using population-based national reference curves (Alexander et al., 1998). Gestational age was computed in weeks as the interval between the last menstrual period and the date of delivery of the fetus. When the menstrual estimate of gestational age was inconsistent with the birth weight (e.g., very low birth weight at term), a clinical estimate of gestational age on the vital records was used instead (Taffel et al., 1982). Dichotomous values were used for birth outcomes.

All demographic information was abstracted from birth certificate data. The variables included racial/ethnic status (white non-Hispanic, black non-Hispanic, Hispanic, or other); maternal age ( $<35$ years or $\geq 35$ years old at time of delivery); marital status (single [which includes women whose marital status was classified as unknown, widowed or divorced] or married); education (less than high school/12 years or high school/12 years or greater); parity (nulliparous or multiparous); pre-pregnancy obesity (obese: body mass index $[\mathrm{BMI}] \geq 30$ or non-obese: $\mathrm{BMI}<30$ ), cigarette smoking during pregnancy (yes or no), and adequacy of prenatal care (adequate or inadequate). BMI computation and comparison were only possible for births after February 2004 since the information for height and pre-pregnancy weight was not collected on the birth certificate 
prior to this date. Adequacy of prenatal care was assessed using the revised graduated index algorithm, which has been found to be more accurate than several others, especially in describing the level of prenatal care utilization among groups that are high risk (Alexander et al., 1996). This index assesses the adequacy of care based on the trimester prenatal care began, number of visits, and the gestational age of the infant at birth. Prepregnancy BMI was calculated from height and pre-pregnancy weight, as recorded on the birth certificate. Maternal demographic characteristics are outlined in Table 2. All of these characteristics are considered potential confounders of birth outcomes and were controlled for in the analysis. Maternal pregnancy complications obtained from the hospital discharge data, based on ICD-9 principal and other diagnostic codes, included anemia, gestational diabetes, diabetes mellitus, gestational hypertension and chronic hypertension, preeclampsia, eclampsia, placental abruption, and placental previa. Researchers have observed improved accuracy with discharge data compared to the birth certificate data in terms of maternal pregnancy complications (Kahn et al., 2009; LydonRochelle et al., 2005). A general logistic/ linear regression model was built to link birth outcomes to exposure level within strata of one zip code. This allowed us to group women according to measuring station and also to each other.

Maternal exposure to air pollution during pregnancy was estimated using date of birth of the infant and the length of each gestational age. This results in weekly exposure data for each pregnancy. Because our interest was in maternal exposure occurring throughout pregnancy since studies have shown that air pollution exposure may interfere with placental development and subsequent oxygen and nutrient delivery to the fetus throughout pregnancy (Lee et al., 2003). Exposure data was then grouped into quartiles 
for each pollutant. The quartiles were grouped so that the lowest $25 \%$ of exposures would serve as the baseline measure. From the quartile exposure data for each pollutant odds ratios and confidence intervals were computed. Adjusted odds ratios were generated after controlling for year of birth, education, maternal age, tobacco use, parity, marital status adequacy of prenatal care, gender of the infant, anemia, gestational diabetes, diabetes mellitus, gestational hypertension, chronic hypertension, preeclampsia, eclampsia, placenta abruption, placenta previa, and renal diseases. Quartile data allowed for the determination of a dose response relationship between exposure dose and risk for adverse fetal morbidity outcome using chi-square test for trend.

To determine which trimesters were critical, we calculated trimester specific exposure outcome odds ratios and confidence intervals. We proceeded by excluding women who delivered before 37 weeks in order to have the full range of exposure in all trimesters. As a result, we decided to limit our outcomes to low birth weight and small for gestational age since a significant proportion of women with preterm birth would not have all trimester values. To this end, we created eight groups based on whether the mother was exposed to above the median level of exposure during the first trimester only, second trimester only, third trimester only, in both first and second trimesters, in both first and third trimesters, in second and third trimesters or in all trimesters. First trimester only exposure groups were from last menstrual period to week 13. The second trimester exposure groups were from week 14 to week 28. The third trimester groups were from week 29 to week 44. Preliminary analysis revealed that mothers were not exposed to above the median level of pollutants during the first trimester only, third trimester only, in both first and second trimesters, in both first and third trimesters. That left us with four 
comparison groups where mothers were exposed to above median levels of pollutants.

The reference group consisted of pregnant mothers who were unexposed in all three trimesters. The second group consisted of pregnant mothers who were exposed to above median levels of pollutants in the second trimester only, while the third group consisted of pregnant mothers who were exposed to above median levels of pollutants in the second trimester and third trimester. The fourth group consisted of pregnant mothers who were exposed in all groups. 


\section{STATISTICAL ANALYSIS}

Exploratory factor analysis was then performed to determine if any of the pollutants could be grouped together to determine if they contributed to the latent factor with similar pattern. The results of this analysis are provided in Table 3. From this analysis, it was determined that primary and secondary pollutants could be grouped together; however, the correlation was weak, and no convergence was achieved when structural equation modeling (SEM) was used.

SEM, also called simultaneous equation model, was used to investigate the association between the mentioned six criteria pollutants (measured as continuous variables) and three categories of birth outcomes (measured as dichotomous variables). SEM is a tool for analyzing multivariate data and set up to model relationships among endogenous and exogenous latent variables, accounting for measurement error. Latent variables summarize the information and reduce the dimension of observed variables. Consequently, SEM is often regarded as more appropriate theoretically because of its ability to capture a series of relationships simultaneously. In this model (Figure 6), let be a 6-dimensional observed vector with continuous elements used to measure a continuous latent variable. $\mathrm{X}$ in our model is pollutant observed. Let $\eta i$ be categorical latent variable and let be a 3-dimensional observed vector with binary elements used to measure a continuous latent variable in our model is the observed outcome. The symbol $\zeta$ represents covariates outlined in table 1 (socio-demographic variables, including age, race, 
education, etc. as previously listed in this section). The term $\xi$ represents errors in the outcome measurements. The term $\delta$ represents errors in the exposure measurements. The symbol $\lambda$ represents the direct effect of latent variables on observed variables. Our model will leave us with a conditional distribution of $\mathrm{y}$ given $\xi$ based on the observed $\mathrm{X}$ and $\mathrm{Y}$ variables calculated with error and covariates taken into consideration. Figure 6 provides a representational model of the observed and latent variables, which was derived from the model in latent class regression on latent factors model. Further explanation of this complex mathematical model can be found in the appendix. 


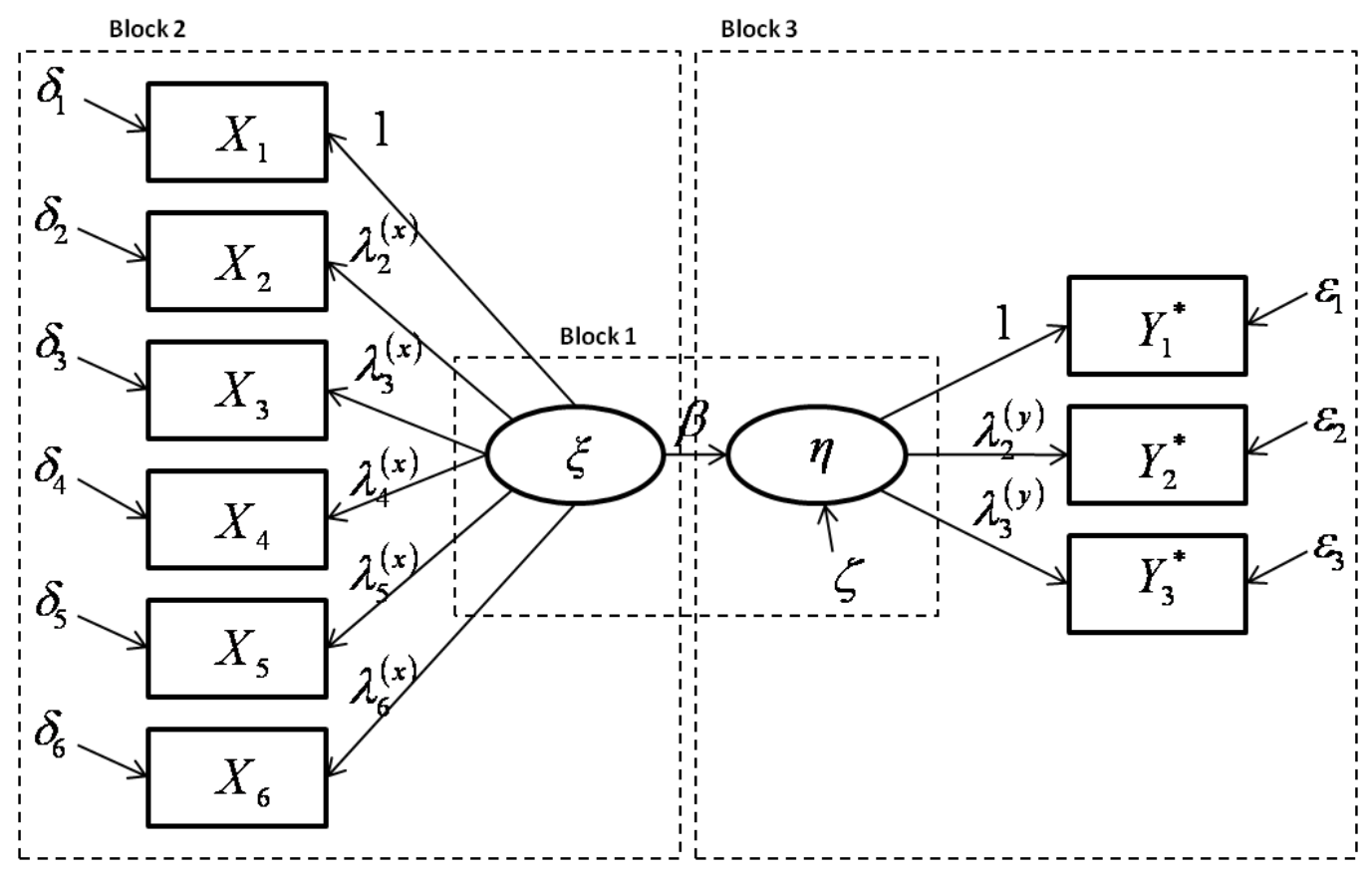

Figure 6: Path diagram composed of the measurement and structural model for the proposed analysis 


\section{RESULTS}

The overall sample consisted of 103,961 singleton births from data years 2000 to 2007. Socio-demographic information of women in the study is presented in Tables 2 and 3. Since a woman can fall within all three exposure categories, p-values were not computed. Maternal socio-demographic information for $\mathrm{Pb}, \mathrm{CO}, \mathrm{PM}_{10}, \mathrm{PM}_{2.5}, \mathrm{NOx}$, and ozone is presented in Table 3. As presented in this table, no significant deviation existed in the socio-demographics or pregnancy complications in all three exposure variables considered in the study. 
Table 2: Maternal demographic characteristic.

\begin{tabular}{|l|c|c|}
\hline Characteristics & Proportion & Frequency \\
\hline Advanced for age ( $\geq 35$ years old) & $13.68 \%$ & 28,517 \\
\hline Education ( $\geq 12$ years) & $66.41 \%$ & 13,847 \\
\hline Married & $59.43 \%$ & 123,912 \\
\hline Smokers & $6.59 \%$ & 13,748 \\
\hline Adequate prenatal care & $99.92 \%$ & 121,136 \\
\hline Obesity * & $8.89 \%$ & 18545 \\
\hline Nulliparity & $33.66 \%$ & 70,185 \\
\hline Race & $51.61 \%$ & 107,608 \\
White & $20.28 \%$ & 42,281 \\
Black & $16.79 \%$ & 35,002 \\
Hispanic & $11.33 \%$ & 2,361 \\
Other & \multicolumn{2}{|c|}{} \\
\hline * Some of the obesity data is missing because it was not reported until after 2004. \\
\hline
\end{tabular}


Table 3: Proportions of demographic characteristics and pregnancy complications among women in the study

\begin{tabular}{|c|c|c|c|c|c|c|}
\hline Characteristics & $\begin{array}{c}\mathrm{CO} \\
\mathrm{n}=199,934\end{array}$ & $\begin{array}{c}\mathrm{Pb} \\
\mathrm{n}=208,216\end{array}$ & $\begin{array}{c}\mathrm{PM}_{10} \\
\mathrm{n}=121.234\end{array}$ & $\begin{array}{c}\mathrm{PM}_{2.5} \\
\mathrm{n}=104,845\end{array}$ & $\begin{array}{c}\text { NO } \\
n=208,198\end{array}$ & $\begin{array}{c}\text { Ozone } \\
\mathrm{n}=208,216\end{array}$ \\
\hline $\begin{array}{l}\text { Race/Ethnicity } \\
\text { White } \\
\text { Black } \\
\text { Hispanics } \\
\text { Other }\end{array}$ & $\begin{array}{l}51.29 \\
20.63 \\
16.95 \\
11.13\end{array}$ & $\begin{array}{c}51.6 \\
20.28 \\
16.8 \\
11.32\end{array}$ & $\begin{array}{c}51.1 \\
20.02 \\
16.45 \\
12.44\end{array}$ & $\begin{array}{l}51.67 \\
20.25 \\
16.81 \\
11.27\end{array}$ & $\begin{array}{c}51.6 \\
20.28 \\
16.8 \\
11.32\end{array}$ & $\begin{array}{c}51.6 \\
20.28 \\
16.8 \\
11.32\end{array}$ \\
\hline $\begin{array}{r}\text { Maternal age } \\
<35 \text { years } \\
\geq 35 \text { years } \\
\end{array}$ & $\begin{array}{l}86.3 \\
13.7 \\
\end{array}$ & $\begin{array}{l}86.33 \\
13.67 \\
\end{array}$ & $\begin{array}{l}86.12 \\
13.88 \\
\end{array}$ & $\begin{array}{l}86.34 \\
13.66 \\
\end{array}$ & $\begin{array}{l}86.33 \\
13.67 \\
\end{array}$ & $\begin{array}{l}86.33 \\
13.67 \\
\end{array}$ \\
\hline $\begin{array}{l}\text { Maternal } \\
\text { education } \\
<12 \text { years } \\
\geq 12 \text { years } \\
\text { Not recorded }\end{array}$ & $\begin{array}{c}19.35 \\
79.92 \\
0.73\end{array}$ & $\begin{array}{c}19.22 \\
80.08 \\
0.7\end{array}$ & $\begin{array}{c}18.94 \\
80.38 \\
0.68\end{array}$ & $\begin{array}{c}19.21 \\
80.09 \\
0.7\end{array}$ & $\begin{array}{c}19.22 \\
80.08 \\
0.7\end{array}$ & $\begin{array}{c}19.22 \\
80.08 \\
0.7\end{array}$ \\
\hline $\begin{array}{c}\text { Marital status } \\
\text { Unmarried } \\
\text { Married } \\
\end{array}$ & $\begin{array}{l}40.66 \\
59.34 \\
\end{array}$ & $\begin{array}{l}40.58 \\
59.42 \\
\end{array}$ & $\begin{array}{l}40.84 \\
59.16 \\
\end{array}$ & $\begin{array}{l}40.51 \\
59.48 \\
\end{array}$ & $\begin{array}{l}40.57 \\
59.42 \\
\end{array}$ & $\begin{array}{l}40.57 \\
59.42 \\
\end{array}$ \\
\hline $\begin{array}{l}\text { Smoking status } \\
\text { Smokers } \\
\text { Non-smokers } \\
\text { Not recorded }\end{array}$ & $\begin{array}{l}92.18 \\
6.57 \\
1.25\end{array}$ & $\begin{array}{c}92.07 \\
6.59 \\
1.33\end{array}$ & $\begin{array}{c}92.13 \\
6.38 \\
1.49\end{array}$ & $\begin{array}{l}92.06 \\
6.61 \\
1.33\end{array}$ & $\begin{array}{l}92.07 \\
6.59 \\
1.33\end{array}$ & $\begin{array}{l}92.07 \\
6.59 \\
1.33\end{array}$ \\
\hline $\begin{array}{l}\text { Parity status } \\
\text { Nulliparous } \\
\text { Multiparous } \\
\text { Not recorded }\end{array}$ & $\begin{array}{c}33.71 \\
65.74 \\
0.55\end{array}$ & $\begin{array}{c}33.67 \\
65.79 \\
0.54\end{array}$ & $\begin{array}{c}33.69 \\
65.72 \\
0.59\end{array}$ & $\begin{array}{l}33.67 \\
65.8 \\
0.53\end{array}$ & $\begin{array}{c}33.67 \\
65.79 \\
0.54\end{array}$ & $\begin{array}{c}33.67 \\
65.79 \\
0.54\end{array}$ \\
\hline $\begin{array}{c}\text { Adequacy of } \\
\text { prenatal care } \\
\text { Inadequate } \\
\text { Adequate }\end{array}$ & $\begin{array}{l}32.74 \\
67.26\end{array}$ & $\begin{array}{l}33.49 \\
66.51\end{array}$ & $\begin{array}{l}34.25 \\
65.75\end{array}$ & $\begin{array}{l}33.44 \\
66.56\end{array}$ & $\begin{array}{l}33.49 \\
66.51\end{array}$ & $\begin{array}{l}33.49 \\
66.51\end{array}$ \\
\hline $\begin{array}{l}\text { Overall pregnancy } \\
\text { complications * } \\
\text { No } \\
\text { Yes }\end{array}$ & $\begin{array}{l}75.8 \\
24.2\end{array}$ & $\begin{array}{l}75.76 \\
24.24\end{array}$ & $\begin{array}{l}75.54 \\
24.46\end{array}$ & $\begin{array}{l}75.73 \\
24.27\end{array}$ & $\begin{array}{l}75.76 \\
24.24\end{array}$ & $\begin{array}{l}75.76 \\
24.24\end{array}$ \\
\hline $\begin{array}{l}\text { * Overall pregnan } \\
\text { of the observed pr } \\
\text { mellitus, gestation } \\
\text { placenta abruption }\end{array}$ & $\begin{array}{l}\text { omplic } \\
\text { ancy co } \\
\text { yperter }\end{array}$ & $\begin{array}{l}\text { s: Comp } \\
\text { cations - } \\
\text { chronic }\end{array}$ & $\begin{array}{l}\text { te varic } \\
\text { nemia, } \\
\text { pertens }\end{array}$ & $\begin{array}{l}\text { for the } \\
\text { ational } \\
\text { preecl }\end{array}$ & $\begin{array}{l}\text { sence of } \\
\text { betes, di } \\
\text { sia, eclo }\end{array}$ & $\begin{array}{l}\text { east one } \\
\text { tes } \\
\text { sia, }\end{array}$ \\
\hline
\end{tabular}


The six criteria pollution levels were also compared to the EPA National Standard (see Table 4). For $\mathrm{CO}$, the mean $( \pm \mathrm{SD})$ was $1.25 \mathrm{ppm}( \pm 0.33)$, range $=0.3$ to $3.075 \mathrm{ppm}$ values; for $\mathrm{Pb}$, the mean $( \pm \mathrm{SD})$ was $0.13 \mathrm{ppm}( \pm 0.1)$, range from 0 to $1.25 \mathrm{ppm}$; for $\mathrm{PM}_{10}$, the mean $( \pm \mathrm{SD})$ was $24.9 \mathrm{ppm}( \pm 4.2 \mathrm{micrograms} / \mathrm{m} 3$, range $=11.5$ to 42 micrograms $/ \mathrm{m} 3$; for $\mathrm{PM}_{2.5}$, the mean $( \pm \mathrm{SD})$ was $11.3( \pm 1.2$ micrograms $/ \mathrm{m} 3)$, range $=7.5$ to 35.8; for NOx, the mean $( \pm \mathrm{SD})$ was $0.02 \mathrm{micrograms} / \mathrm{m} 3( \pm 0.004)$, range $=0.01$ to 0.04 micrograms/m3; and for ozone, the mean $( \pm \mathrm{SD})=0.04 \mathrm{ppm}( \pm 0.004)$, range $=0.03$ to 0.05 ppm. The proportions of pregnancy complications within the study population, as compared to national averages, are reported in Table 5, while the frequencies of preterm births, small for gestational age, and low birth weight are reported in Table 6 . These values are also compared to national averages.

Additionally, the results of the exploratory factor analysis are shown in Table 7. Ozone and particulate matter (PM), which are primary and secondary pollutants, respectively, and were grouped together based on the correlation data in table 6 . Furthermore, $\mathrm{CO}, \mathrm{SO}_{2}$, $\mathrm{NOx}$, and lead were grouped together. $\mathrm{CO}, \mathrm{SO}_{4}, \mathrm{NOx}$, and lead are primary pollutants.

Table 8 resents maximum likelihood estimates for the parameters of the model along with the goodness of fit statistics (RMSEA, CFI, TLI). We also estimated the model when all observations from the analysis that had missing values on one or more of the variables were deleted. Even though the model fitted the data in both scenarios, the model that had missing data deleted fit the data better. The estimate (as presented in Table 8 ) of 0.35 with a confidence interval of 0.17 to 0.53 suggests an association between higher pollutant levels and adverse feto-infant morbidity outcomes. 
Table 4: EPA National Air Pollution Standards compared to pollutant levels in Hillsborough County, Florida (2000-2007) (EPA, 2009)

\begin{tabular}{|l|c|c|c|}
\hline \multicolumn{1}{|c|}{ Pollutants } & $\begin{array}{c}\text { Hillsborough } \\
\text { County } \\
\text { Average }\end{array}$ & $\begin{array}{c}\text { Hillsborough } \\
\text { County } \\
\text { Range }\end{array}$ & $\begin{array}{c}\text { National } \\
\text { Standard }\end{array}$ \\
\hline $\mathrm{CO}(\mathrm{ppm})$ & $1.25 \mathrm{ppm}$ & $0.3-3.057 \mathrm{ppm}$ & $9 \mathrm{ppm} \mathrm{per} 8 \mathrm{hrs}$. \\
\hline $\mathrm{NO}(\mathrm{micrograms} / \mathrm{m} 3)$ & $0.02 \mathrm{ug} / \mathrm{m} 3$ & $0.01-0.04 \mathrm{ug} / \mathrm{m} 3$ & $0.053 \mathrm{ug} / \mathrm{m} 3$ \\
\hline $\mathrm{Pb}(\mathrm{ppm})$ & $0.13 \mathrm{ppm}$ & $0-1.25 \mathrm{ppm}$ & $1.5 \mathrm{ppm}$ \\
\hline $\mathrm{Ozone}(\mathrm{ppm})$ & $0.04 \mathrm{ppm}$ & $0.03-0.05 \mathrm{ppm}$ & $0.075 \mathrm{ppm}$ \\
\hline $\mathrm{PM}_{10}$ & $4.2 \mathrm{ug} / \mathrm{m} 3$ & $11.5-42 \mathrm{ug} / \mathrm{m} 3$ & $150 \mathrm{ug} / \mathrm{m} 3$ \\
\hline $\mathrm{PM}_{2.5}$ & $11.3 \mathrm{ug} / \mathrm{m} 3$ & $7.5-35.8 \mathrm{ug} / \mathrm{m} 3$ & $35.0 \mathrm{ug} / \mathrm{m} 3$ \\
\hline
\end{tabular}

Table 5: National proportion of pregnancy complications compared to those in Hillsborough County, Florida (2000-2007) (WHO, 2007)

\begin{tabular}{|l|c|c|c|}
\hline Pregnancy Complications & Proportion & Frequency & National \% \\
\hline Anemia & $9.97 \%$ & 187717 & $18 \%$ \\
\hline Gestational diabetes & $5.72 \%$ & 11937 & $2-10 \%$ \\
\hline Diabetes mellitus & $0.71 \%$ & 1480 & $8.30 \%$ \\
\hline Gestational hypertension & $4.82 \%$ & 10058 & $5-7 \%$ \\
\hline Chronic hypertension & $1.45 \%$ & 3019 & $8-10 \%$ \\
\hline Preeclampsia & $3.70 \%$ & 7721 & $4-6 \%$ \\
\hline Eclampsia & $0.07 \%$ & 150 & $4 \%$ \\
\hline Abruption & $0.85 \%$ & 1582 & $0.40 \%$ \\
\hline
\end{tabular}

Table 6: National infant morbidity statistics compared to those in Hillsborough County, Florida (2000-2007) (WHO, 2008)

\begin{tabular}{|l|c|c|c|}
\hline \multicolumn{1}{|c|}{ Infant Morbidity } & Proportion & Frequency & National \% \\
\hline Pre-term birth & $9067 / 99671$ & $9.10 \%$ & $12.20 \%$ \\
\hline Small for gestational age & $8412 / 99671$ & $8.40 \%$ & $14 \%$ \\
\hline Low Birth Weight & $6420 / 99671$ & $6.40 \%$ & $8.20 \%$ \\
\hline
\end{tabular}


Table 7: Results of Exploratory Factor Analysis

\begin{tabular}{|l|c|c|}
\hline \multicolumn{1}{|c|}{ Pollutants } & 1 Factor $*$ & 2 Factors $*$ \\
\hline $\mathrm{PB}$ & -0.57 & -0.221 \\
\hline $\mathrm{NO}$ & 0.888 & -0.011 \\
\hline $\mathrm{CO}$ & 0.588 & 0.004 \\
\hline Ozone & -0.288 & 0.641 \\
\hline $\mathrm{PM}_{2.5}$ & 0.481 & 0.622 \\
\hline $\mathrm{PM}_{10}$ & -0.129 & 0.166 \\
\hline * Factor $1=\mathrm{Pb}, \mathrm{NO}, \mathrm{CO}, \mathrm{PM} 10 ;$ Factor 2=Ozone, PM25, $\mathrm{PM}$ \\
\hline
\end{tabular}

Table 8: Parameter estimates from structural equation modeling

\begin{tabular}{|l|c|c|c|c|c|c|}
\hline & \multicolumn{2}{|c|}{ Without missing values } & \multicolumn{3}{c|}{ With missing values } \\
\hline & Estimate & S.E. $*$ & P-Value & Estimate & S.E. $^{*}$ & P-Value \\
\hline B & 0.42 & 0.1 & $<0.001$ & 0.35 & 0.09 & $<0.001$ \\
\hline RMSEA & 0.058 & & & 0.062 & & \\
\hline CFI & 0.963 & & & 0.953 & & \\
\hline TLI & 0.949 & & & 0.935 & & \\
\hline$*$ S.E. = Standard Error & & & & \\
\hline
\end{tabular}

The quartile data demonstrates OR that were significant for a relationship between $\mathrm{PM}_{2.5}$ and $\mathrm{PM}_{10}$ in the upper quartile for $\mathrm{LBW}\left(\mathrm{PM}_{2.5}: \mathrm{OR}=1.152,95 \%\right.$ $\left.\mathrm{CI}=1.052-1.253 ; \mathrm{PM}_{10}: \mathrm{OR}=1.179,95 \% \mathrm{CI}=1.103-1.260\right)$ and $\mathrm{VLBW}\left(\mathrm{PM}_{2.5}: \mathrm{OR}=1.19\right.$, 95\% $\left.\mathrm{CI}=1.02-1.4 ; \mathrm{PM}_{10}: \mathrm{OR}=1.2,95 \% \mathrm{CI}=1.007-1.43\right) . \mathrm{PM}_{10}$ also demonstrated an $\mathrm{OR}$ that was significant in the upper quartile for SGA $(\mathrm{OR}=1.116,95 \% \mathrm{CI}-1.052-1.184)$. Nitrous oxide (NOx) demonstrated a significant association in the middle and upper quartiles for $\mathrm{LBW}$ (middle quartile: $\mathrm{OR}=1.15,95 \% \mathrm{CI}=1.093-1.217$; upper quartile: $\mathrm{OR}=1.11,95 \% \mathrm{CI}=1.041-1.185)$. There was also a significant association in the middle quartile for preterm outcomes $(\mathrm{OR}$ middle quartile $=1.09,95 \% \mathrm{CI}=1.046-1.145)$ but not 
for the upper or lower quartile. Nitrous oxide (NOx) also demonstrated a significant association in all quartiles for small for gestational age (lower quartile: $\mathrm{OR}=1.08,95 \%$ $\mathrm{CI}=1.033-1.132$; middle quartile: $\mathrm{OR}=1.15,95 \% \mathrm{CI}=1.098-1.209$; upper quartile: $\mathrm{OR}=1.2,95 \% \mathrm{CI}=1.32-1.270)$. Carbon monoxide $(\mathrm{CO})$ demonstrated a significant relationship in the upper and lower quartile for low birth weight (upper quartile: $\mathrm{OR}=1.15,95 \% \mathrm{CI}=1.083-1.224$; lower quartile: $\mathrm{OR}=1.15,95 \% \mathrm{CI}=1.093-1.210)$ and small for gestational age outcomes (lower quartile: $\mathrm{OR}=1.08 ; 95 \% \mathrm{CI}=1.032-1.130$; upper quartile: $\mathrm{OR}=1.12 ; 95 \% \mathrm{CI}=1.066-1.186)$ but not for the middle quartile. $\mathrm{CO}$ also demonstrated a significant association in all quartiles for preterm birth (lower quartile: $\mathrm{OR}=1.18,95 \% \mathrm{CI}=1.131-1.234$; middle quartile: $\mathrm{OR}=1.06,95 \% \mathrm{CI}=1.016-1.112$; upper quartile: $\mathrm{OR}=1.16,95 \% \mathrm{CI}=1.101-1.219)$. VPTB did not show any significant relationship. 
Table 9: Quartile data OR and CI compared across pollutants and outcomes *

\begin{tabular}{|c|c|c|c|c|c|c|c|c|c|c|}
\hline & \multicolumn{2}{|c|}{ LBW } & \multicolumn{2}{|c|}{ PTB } & \multicolumn{2}{|c|}{ SGA } & \multicolumn{2}{|c|}{ VLBW } & \multicolumn{2}{|c|}{ VPTB } \\
\hline & OR & $95 \% \mathrm{CI}$ & OR & $95 \% \mathrm{CI}$ & OR & $95 \% \mathrm{CI}$ & OR & $95 \% \mathrm{CI}$ & OR & $95 \% \mathrm{CI}$ \\
\hline \multicolumn{11}{|c|}{$\mathbf{P M}_{2.5}$} \\
\hline $\begin{array}{l}\text { Lower } \\
\text { Quartile }\end{array}$ & 0.91 & $0.85-0.98$ & 0.89 & $\begin{array}{c}0.841- \\
0.951\end{array}$ & 1.05 & $\begin{array}{c}0.990- \\
1.124\end{array}$ & 0.673 & $\begin{array}{c}0.560- \\
0.810\end{array}$ & 0.721 & $\begin{array}{c}0.608- \\
0.854\end{array}$ \\
\hline $\begin{array}{l}\text { Middle } \\
\text { Quartile }\end{array}$ & 1.02 & $0.95-1.10$ & 1.01 & $\begin{array}{c}0.949- \\
1.070\end{array}$ & 1.05 & $\begin{array}{c}0.985- \\
1.118\end{array}$ & 0.723 & $\begin{array}{c}0.605- \\
0.865\end{array}$ & 0.71 & $\begin{array}{c}0.6- \\
0.840\end{array}$ \\
\hline $\begin{array}{l}\text { Upper } \\
\text { Quartile }\end{array}$ & 1.15 & $1.05-1.25$ & 1.05 & $\begin{array}{c}0.976- \\
1.138\end{array}$ & 1.05 & $\begin{array}{c}0.971- \\
1.143\end{array}$ & 1.194 & $\begin{array}{l}1.016- \\
1.403\end{array}$ & 1.132 & $\begin{array}{c}0.971- \\
1.32\end{array}$ \\
\hline \multicolumn{11}{|c|}{$\mathbf{P M}_{10}$} \\
\hline $\begin{array}{l}\text { Lower } \\
\text { Quartile }\end{array}$ & 1.05 & $\begin{array}{c}0.981- \\
1.124\end{array}$ & 0.98 & $\begin{array}{c}0.921- \\
1.032\end{array}$ & 1 & $\begin{array}{c}0.928- \\
1.046\end{array}$ & 0.997 & $\begin{array}{c}0.828- \\
1.200\end{array}$ & 0.995 & $\begin{array}{c}0.839- \\
1.181\end{array}$ \\
\hline $\begin{array}{l}\text { Middle } \\
\text { Quartile }\end{array}$ & 1.07 & $\begin{array}{c}0.998- \\
1.43 \\
\end{array}$ & 1.06 & $\begin{array}{l}0.997- \\
1.117 \\
\end{array}$ & 1.04 & $\begin{array}{c}0.976- \\
1.101\end{array}$ & 1.072 & $\begin{array}{c}0.893- \\
1.288\end{array}$ & 1 & $\begin{array}{c}0.843- \\
1.186\end{array}$ \\
\hline $\begin{array}{l}\text { Upper } \\
\text { Quartile }\end{array}$ & 1.18 & $\begin{array}{l}1.103- \\
1.260\end{array}$ & 1.04 & $\begin{array}{c}0.983- \\
1.101\end{array}$ & 1.12 & $\begin{array}{c}1.052- \\
1.184\end{array}$ & 1.201 & $\begin{array}{l}1.007- \\
1.433\end{array}$ & 1.088 & $\begin{array}{c}0.922- \\
1.283\end{array}$ \\
\hline \multicolumn{11}{|c|}{ Carbon Monoxide } \\
\hline $\begin{array}{l}\text { Lower } \\
\text { Quartile }\end{array}$ & 1.15 & $\begin{array}{l}1.093- \\
1.210\end{array}$ & 1.18 & $\begin{array}{l}1.131- \\
1.234\end{array}$ & 1.08 & $\begin{array}{c}1.032- \\
1.130 \\
\end{array}$ & 1.021 & $\begin{array}{c}0.857- \\
1.217 \\
\end{array}$ & 1.027 & $\begin{array}{c}0.869- \\
1.213\end{array}$ \\
\hline $\begin{array}{l}\text { Middle } \\
\text { Quartile }\end{array}$ & 0.97 & $\begin{array}{l}0.923- \\
1.027\end{array}$ & 1.06 & $\begin{array}{l}1.016- \\
1.112\end{array}$ & 1.03 & $\begin{array}{c}0.989- \\
1.085\end{array}$ & 0.816 & $\begin{array}{c}0.679- \\
0.981\end{array}$ & 0.866 & $\begin{array}{c}0.728- \\
1.029\end{array}$ \\
\hline $\begin{array}{l}\text { Upper } \\
\text { Quartile } \\
\end{array}$ & 1.15 & $\begin{array}{l}1.083- \\
1.224 \\
\end{array}$ & 1.16 & $\begin{array}{l}1.101- \\
1.219\end{array}$ & 1.12 & $\begin{array}{l}1.066- \\
1.186 \\
\end{array}$ & 0.946 & $\begin{array}{c}0.791- \\
1.32 \\
\end{array}$ & 0.981 & $\begin{array}{c}0.829- \\
1.162 \\
\end{array}$ \\
\hline \multicolumn{11}{|c|}{ Nitrogen Dioxide } \\
\hline $\begin{array}{l}\text { Lower } \\
\text { Quartile }\end{array}$ & 1 & $\begin{array}{c}0.0948 \text { - } \\
1.051\end{array}$ & 0.93 & $\begin{array}{c}0.889- \\
0.971\end{array}$ & 1.08 & $\begin{array}{l}1.033- \\
1.132\end{array}$ & 0.793 & $\begin{array}{c}0.662- \\
0.949\end{array}$ & 0.783 & $\begin{array}{l}0.66- \\
0.928\end{array}$ \\
\hline $\begin{array}{l}\text { Middle } \\
\text { Quartile } \\
\end{array}$ & 1.15 & $\begin{array}{l}1.093- \\
1.217\end{array}$ & 1.09 & $\begin{array}{l}1.046- \\
1.145\end{array}$ & 1.15 & $\begin{array}{c}1.098- \\
1.209\end{array}$ & 0.521 & $\begin{array}{c}0.231- \\
1.175 \\
\end{array}$ & 0.554 & $\begin{array}{c}0.261- \\
1.179 \\
\end{array}$ \\
\hline $\begin{array}{l}\text { Upper } \\
\text { Quartile }\end{array}$ & 1.11 & $\begin{array}{l}1.041- \\
1.185\end{array}$ & 1.03 & $\begin{array}{c}0.975- \\
1.088\end{array}$ & 1.2 & $\begin{array}{l}1.32- \\
1.270\end{array}$ & 0.86 & $\begin{array}{c}0.717- \\
1.031\end{array}$ & 0.897 & $\begin{array}{c}0.756- \\
1.064\end{array}$ \\
\hline
\end{tabular}




\begin{tabular}{|c|c|c|c|c|c|c|c|c|c|c|}
\hline \multicolumn{11}{|c|}{ Lead } \\
\hline $\begin{array}{l}\text { Lower } \\
\text { Quartile }\end{array}$ & 0.95 & $\begin{array}{c}0.905- \\
1.003\end{array}$ & 0.96 & $\begin{array}{c}0.918- \\
1.001\end{array}$ & 0.95 & $\begin{array}{c}0.909- \\
0.995\end{array}$ & 1.012 & $\begin{array}{l}0.85- \\
1.205\end{array}$ & 1.002 & $\begin{array}{c}0.849- \\
1.183\end{array}$ \\
\hline $\begin{array}{l}\text { Middle } \\
\text { Quartile }\end{array}$ & 0.77 & $\begin{array}{c}0.725- \\
0.817\end{array}$ & 0.87 & $\begin{array}{c}0.828- \\
0.916\end{array}$ & 0.92 & $\begin{array}{c}0.873- \\
0.968\end{array}$ & 0.742 & $\begin{array}{c}0.612- \\
0.899\end{array}$ & 0.74 & $\begin{array}{c}0.62- \\
0.89\end{array}$ \\
\hline $\begin{array}{l}\text { Upper } \\
\text { Quartile }\end{array}$ & 0.93 & $\begin{array}{c}0.878- \\
0.986\end{array}$ & 1.03 & $\begin{array}{c}0.981- \\
1.083\end{array}$ & 0.9 & $\begin{array}{l}0.851- \\
0.945\end{array}$ & 1.087 & $\begin{array}{c}0.914- \\
1.292\end{array}$ & 1.137 & $\begin{array}{c}0.966- \\
1.338\end{array}$ \\
\hline \multicolumn{11}{|c|}{ Ozone } \\
\hline $\begin{array}{l}\text { Lower } \\
\text { Quartile }\end{array}$ & 0.86 & $\begin{array}{c}0.814- \\
0.899\end{array}$ & 0.84 & $\begin{array}{c}0.809- \\
0.880\end{array}$ & 1.01 & $\begin{array}{c}0.966- \\
1.055\end{array}$ & 0.693 & $\begin{array}{l}0.582- \\
0.825\end{array}$ & 0.659 & $\begin{array}{c}0.561- \\
0.775\end{array}$ \\
\hline $\begin{array}{l}\text { Middle } \\
\text { Quartile }\end{array}$ & 0.82 & $\begin{array}{c}0.781- \\
0.864\end{array}$ & 0.79 & $\begin{array}{c}0.761- \\
0.829\end{array}$ & 1 & $\begin{array}{c}0.947- \\
1.036\end{array}$ & 0.687 & $\begin{array}{c}0.575- \\
0.820\end{array}$ & 0.601 & $\begin{array}{c}0.508- \\
0.711\end{array}$ \\
\hline $\begin{array}{l}\text { Upper } \\
\text { Quartile }\end{array}$ & 0.93 & $\begin{array}{c}0.888- \\
0.980 \\
\end{array}$ & 0.88 & $\begin{array}{c}0.846- \\
0.920\end{array}$ & 1.02 & $\begin{array}{c}0.938- \\
1.027\end{array}$ & 0.954 & $\begin{array}{c}0.809- \\
1.126\end{array}$ & 0.869 & $\begin{array}{c}0.745- \\
1.014\end{array}$ \\
\hline \multicolumn{11}{|c|}{$\begin{array}{l}\text { Abbreviations: } L B W=\text { Low Birth Weight; PTB = Preterm Birth; SGA = Small for Gestational Age; VLBW = Very Low Birth } \\
\text { Weight; VPTB = Very Preterm Birth; OR = Odds Ratio; } C I=\text { Confidence Intervals } \\
\text { * Significant values in bold font. }\end{array}$} \\
\hline
\end{tabular}


Chi-square for linear dose-response relationships was performed, and results are provided in Table 10. Significant p-values demonstrated that there was a significant dose response for $\mathrm{PM}_{2.5}$ and $\mathrm{PM}_{10}$ for $\mathrm{VLBW}$. Ozone had a significant dose response for all outcomes. Lead had a significant dose response for preterm outcomes. Nitrogen dioxide $\left(\mathrm{NO}_{2}\right)$ had a significant dose response for SGA outcomes. CO had no significant dose response. See table 9 for quartile data OR and CI compared across pollutants and outcomes. See table 10 for Mentel-Haenszel Chi Squared P value for adjusted quartile data. 
Table 10: Mantel-Haenszel Chi Square P-Values for Adjusted Quartile data *

\begin{tabular}{|c|c|c|c|c|c|}
\hline Pollutants & LBW & VLBW & PTB & VPTB & SGA \\
\hline PM 2.5 & 0.781 & 0.0319 & 0.8573 & 0.2269 & 0.7386 \\
\hline PM 10 & 0.0001 & 0.0002 & 0.0109 & 0.009 & 0.0001 \\
\hline Carbon Monoxide & 0.944 & 0.623 & 0.0765 & 0.9004 & 0.0909 \\
\hline Nitrogen Dioxide & 0.6715 & 0.4831 & 0.5987 & 0.6161 & 0.0112 \\
\hline Lead & 0.28 & 0.85 & 0.0449 & 0.3187 & 0.499 \\
\hline Ozone & 0.0011 & 0.05 & 0.0001 & 0.0007 & 0.0173 \\
\hline
\end{tabular}


Results for the trimester group data demonstrated significant relationship between $\mathrm{PM}_{10}$ and LBW, VLBW, and SGA when the mother was exposed to above median levels for all three trimesters (LBW: OR=1.15, 95\% CI=1.066-1.228; VLBW: $\mathrm{OR}=1.2,95 \%$ $\mathrm{CI}=1.007-1.433$; SGA: OR=1.122, 95\% CI=1.054-1.195) (Table 11). $\mathrm{PM}_{2.5}$ demonstrated a significant relationship to VLBW when the mother was exposed in all trimesters $(\mathrm{OR}=1.194,95 \% \mathrm{CI}=1.016-1.403)$. Carbon monoxide $(\mathrm{CO})$ demonstrated a significant relationship to LBW and SGA in the second trimester only (LBW: OR=1.15, 95\% $\mathrm{CI}=1.068-1.232 ; \mathrm{SGA}: \mathrm{OR}=1.097 ; 95 \% \mathrm{CI}=1.029-1.169)$. Lead demonstrated a significant relationship to LBW when the mother was exposed in all trimesters $(\mathrm{OR}=1.11,95 \% \mathrm{CI}=1.028-1.184)$. No deleterious relationship was demonstrated for ozone or nitrogen oxides. 
Table 11: Trimester data OR and CI compared across pollutants and outcomes

\begin{tabular}{|c|c|c|c|c|c|c|}
\hline & \multicolumn{2}{|c|}{ LBW } & \multicolumn{2}{|c|}{ VLBW } & \multicolumn{2}{|c|}{ SGA } \\
\hline & $\overline{\text { OR }}$ & $95 \% \mathrm{CI}$ & OR & $95 \% \mathrm{CI}$ & $\overline{\text { OR }}$ & $95 \% \mathrm{CI}$ \\
\hline \multicolumn{7}{|c|}{$\mathbf{P M}_{2.5}$} \\
\hline 2nd Trimester only & 0.91 & $\begin{array}{c}0.846- \\
0.974\end{array}$ & 0.673 & $\begin{array}{c}0.560- \\
0.810\end{array}$ & 1.03 & $\begin{array}{c}0.971- \\
1.10\end{array}$ \\
\hline 1 st and 3rd Trimester & 0.97 & $\begin{array}{l}0.820- \\
1.025\end{array}$ & 0.723 & $\begin{array}{c}0.605- \\
0.865\end{array}$ & 1.06 & $\begin{array}{c}0.991- \\
1.122\end{array}$ \\
\hline All Trimester & 0.98 & $\begin{array}{c}0.909- \\
1.046\end{array}$ & 1.194 & $\begin{array}{l}1.016- \\
1.403\end{array}$ & 1.01 & $\begin{array}{l}0.94- \\
1.071\end{array}$ \\
\hline \multicolumn{7}{|c|}{$\mathbf{P M}_{10}$} \\
\hline 2nd Trimester only & 1.03 & $\begin{array}{c}0.952- \\
1.101\end{array}$ & 1 & $\begin{array}{c}0.828- \\
1.2\end{array}$ & 1 & $\begin{array}{c}0.938- \\
1.067\end{array}$ \\
\hline 1st and 3rd Trimester & 1.05 & $\begin{array}{c}0.971- \\
1.122\end{array}$ & 1.07 & $\begin{array}{c}0.893- \\
1.288\end{array}$ & 1.03 & $\begin{array}{c}0.963- \\
1.094\end{array}$ \\
\hline All Trimester & 1.15 & $\begin{array}{l}1.066- \\
1.228\end{array}$ & 1.2 & $\begin{array}{l}1.007- \\
1.433\end{array}$ & 1.122 & $\begin{array}{l}1.054- \\
1.195\end{array}$ \\
\hline \multicolumn{7}{|c|}{ Carbon Monoxide } \\
\hline 2nd Trimester only & 1.15 & $\begin{array}{c}1.068- \\
1.232\end{array}$ & 1.02 & $\begin{array}{c}0.857- \\
1.217 \\
\end{array}$ & 1.097 & $\begin{array}{c}1.029- \\
1.169\end{array}$ \\
\hline 1st and 3rd Trimester & 0.92 & $\begin{array}{c}0.853- \\
0.989\end{array}$ & 0.82 & $\begin{array}{c}0.679- \\
0.981\end{array}$ & 1.015 & $\begin{array}{c}0.950- \\
1.082\end{array}$ \\
\hline All Trimester & 0.99 & $\begin{array}{c}0.923- \\
1.067\end{array}$ & 0.947 & $\begin{array}{c}0.791- \\
1.132 \\
\end{array}$ & 1.037 & $\begin{array}{c}0.972- \\
1.107\end{array}$ \\
\hline \multicolumn{7}{|c|}{ Nitrogen Dioxide } \\
\hline 2nd Trimester only & 0.93 & $\begin{array}{c}0.865- \\
0.998\end{array}$ & 0.8 & $\begin{array}{c}0.662- \\
0.949\end{array}$ & 1.05 & $\begin{array}{c}0.982- \\
1.115\end{array}$ \\
\hline 1st and 3rd Trimester & 0.71 & $\begin{array}{c}0.531- \\
0.936 \\
\end{array}$ & 0.52 & $\begin{array}{c}0.231- \\
1.175 \\
\end{array}$ & 1.01 & $\begin{array}{c}0.803- \\
1.264 \\
\end{array}$ \\
\hline All Trimester & 0.91 & $\begin{array}{c}0.845- \\
0.979\end{array}$ & 0.86 & $\begin{array}{c}0.717- \\
1.031\end{array}$ & 1.07 & $\begin{array}{l}1.00- \\
1.140\end{array}$ \\
\hline \multicolumn{7}{|c|}{ Lead } \\
\hline 2nd Trimester only & 1.02 & $\begin{array}{c}0.83- \\
1.44 \\
\end{array}$ & 1.012 & $\begin{array}{c}0.850- \\
1.205 \\
\end{array}$ & 1 & $\begin{array}{c}0.920- \\
1.043 \\
\end{array}$ \\
\hline $1^{\text {st }}$ and 3 rd Trimester & 0.91 & $\begin{array}{c}0.846- \\
0.982\end{array}$ & 0.74 & $\begin{array}{c}0.612- \\
0.899\end{array}$ & 1 & $\begin{array}{l}0.93- \\
1.057\end{array}$ \\
\hline All Trimester & 1.11 & $\begin{array}{c}1.028- \\
1.184\end{array}$ & 1.09 & $\begin{array}{c}0.914- \\
1.292\end{array}$ & 1 & $\begin{array}{c}0.916- \\
1.041\end{array}$ \\
\hline \multicolumn{7}{|c|}{ Ozone } \\
\hline 2nd Trimester only & 0.85 & $\begin{array}{c}0.793- \\
0.912\end{array}$ & 0.7 & $\begin{array}{c}0.582- \\
0.825\end{array}$ & 1 & $\begin{array}{c}0.943- \\
1.069\end{array}$ \\
\hline $1^{\text {st }}$ and 3rd Trimester & 0.863 & 0.804- & 0.687 & $0.575-$ & 1.01 & 0.946- \\
\hline
\end{tabular}




\begin{tabular}{|l|c|c|c|c|c|c|}
\hline & & $\mathbf{0 . 9 2 5}$ & & $\mathbf{0 . 8 2 0}$ & & 1.072 \\
\hline All Trimester & 0.972 & $\begin{array}{c}0.907- \\
1.042\end{array}$ & 0.96 & $\begin{array}{c}0.809- \\
1.126\end{array}$ & 1 & $\begin{array}{c}0.931- \\
1.057\end{array}$ \\
\hline Abbreviations: $L B W=$ Low Birth Weight; PTB = Preterm Birth; SGA = Small for \\
Gestational Age; VLBW = Very Low Birth Weight; VPTB = Very Preterm Birth; OR = \\
Odds Ratio; CI = Confidence Intervals \\
* Significant values in bold font. \\
?
\end{tabular}




\section{DISCUSSION AND CONCLUSION}

Socio-demographic data of this study demonstrated no great deviation existed in the demographic or pregnancy complications in all exposure variables considered in the study. Pregnancy complications and morbidity outcomes were below the national percentages. Criteria pollutant ranges were also reported to be below the National Standards. When exploratory factor analysis was performed, primary and secondary pollutants did have some correlation, but it could not be adequately modeled by our SEM approach. The significant B value from our latent regression model is 0.35 . This indicates that exposure to the six criteria pollutant in pregnancy may have a significant relationship to all five birth outcomes if they are broken down into latent variables. Explanation of this modeling is beyond the scope of this thesis and will be looked at further in future studies.

NOx seemed to have most significant associations with all outcomes with a dose response for SGA. NOx, however, had no significant response if the exposure was classified as an above median level and was broken down into trimesters. $\mathrm{CO}$ also had significant responses; however, the dose -response relationship did not support this association. $\mathrm{CO}$ did have a significant response if the data was broken down into trimesters. It demonstrated a significant relationship in the $2^{\text {nd }}$ trimester for LBW, as well as for SGA. PM 10 and $\mathrm{PM}_{2.5}$ had some association to LBW and VLBW at high levels. $\mathrm{PM}_{10}$ demonstrated significance in the higher doses for SGA. The only dose-response 
relationship that was demonstrated for $\mathrm{PM}_{10}$ and $\mathrm{PM}_{2.5}$ was in VLBW. $\mathrm{PM}_{10}$ also demonstrated a dose response with very preterm; however, none of the individual results were significant. If sub-divided into trimester data, $\mathrm{PM}_{10}$ demonstrated a significant relationship between exposures in all trimesters and LBW, VLBW, and SGA. PM 2.5 demonstrated a significant relationship between exposures in all trimesters and VLBW. Ozone did not demonstrate any significance in quartile or trimester data; however, it did show a dose response for all outcomes. Lead did not demonstrate any significance in quartile data and only demonstrated significance in the trimester data if the mother was exposed in all trimesters.

From this data it can be suggested that $\mathrm{PM}_{10}$ demonstrated the most significance using all statistical approaches. This study also produces many of the same results as prior studies. Multiple studies have also found an association between $\mathrm{PM}_{10}$ and $\mathrm{LBW}$ (Dejmek et al., 1999; Gouveia et al., 2004; Ha et al., 2001; Jedrychowski, et al. 2004; Wang et al., 1998). $\mathrm{PM}_{2.5}$ did not have the same strength of association as $\mathrm{PM}_{10}$. However, it is important to note that other studies only found an association when stratified for race (Maisonet et al., 2001). Similar to previous research, CO was associated with low birth weight (Gouveia et al., 2004; Ha et al., 2001; Maisonet et al., 2001; Mannes et al., 2005; Ritz et al., 2000; Salam et al., 2005). However, these studies did not assess dose-response as we did in our analysis.

Unlike other studies, NOx did not show any significant results based on trimester (Ballester et al., 2010; Bobak et al., 2009; Landgren et al., 1996). However, in these studies, the results demonstrated significance for preterm delivery, which we controlled 
for, since this could not produce valid results, as there was no comparison group for certain trimesters.

It can also be concluded that ozone had the least significance of the air pollutants under investigation. In our study, ozone did not have any significant effect on birth outcomes. However, in a study by Hanson and colleagues (2009), there was an association with aortic artery and valve defects. We did not assess these outcomes in our analysis. Additional outcome variables would have made this study more robust and possibly contribute to the overall understanding of the pathophysiology.

The suspected pathophysiology of morbidity and mortality from air pollution remains to be determined; however, scientists have suggested different theories, including disturbances of the pituitary-adrenocortico-placental system, disturbances of the uterine blood flow, and increased maternal susceptibility to infections. All of these effects could lead to premature rupture of membranes or premature contractions, resulting in preterm birth. $\mathrm{CO}$ causes low $\mathrm{O}_{2}$ flow to organs and, thus, creates slowed or delayed growth. NOx possibly affects lungs of mothers, which could contribute to decreased maternal $\mathrm{O}_{2}$ flow to fetus. $\mathrm{PM}_{2.5}$ penetrates deeper into the lungs, and, even though it is not clear how exactly they restrict fetal growth, some studies have shown that they alter cell activity or reduce the amount of oxygen and nutrients the fetus receives in utero (Rich, et al., 2009). Some obvious strengths of this study include the study power and intrinsic temporality of the study. We had data for births from 2000 to 2007 and air pollution records for the same period. We controlled for several potential confounders, although we cannot rule out residual confounding due to unmeasured variables, as well as the determination of exposure by residential zip code. 
A limitation of this study included the exposure analysis. The exposed group was created based on a population-level estimation of the values of the particulate pollutants, rather than the actual amount/concentration of the particulates detected in the individual's biologic sample (e.g., maternal blood). There is, therefore, a possibility of exposure misclassification because county-wide monitors were used to capture exposures at the individual level. This limitation is, however, not peculiar to our study, as other investigators have also had to manage this measurement error (Ballester et al., 2010; Hansen et al., 2009; Lee et al., 2003; Wooddruff et al., 1997). We were also unable to control for individual exposure variability induced by other factors, including distance from roads, traffic, place of work, seasonality, and period of time spent at the current address. Studies have also shown that $12-33 \%$ of women move from their initial address during pregnancy (Hansen et al., 2009), a potential source of non-differential misclassification, which could have led to an underestimate of the association between the three pollutants and feto-infant morbidity outcomes examined in this study. Measurement error could also be present if mothers spent a considerable amount of time outside of the perimeter of the residential air monitoring station.

The exploratory analysis data suggested that possibly air pollutants could be grouped together based on primary and secondary status. However, when further SEM analysis was performed, convergence was not obtained. This seems to suggest that the correct model takes into account that all pollutants simultaneously have the observed associated outcome and that possibly the pollutants taken as separate will not have as strong of an association. This may even contribute to the mixed results that prior studies 
demonstrated using means and individually selecting relationships between exposures and birth outcome.

An excellent epidemiologic study to add to the body of knowledge of the cause of the disease would be a nested case-control study within a prospective cohort. This would be an important model in this type of study because the cases and controls come from the same well-defined population. This has the advantage of minimizing selection bias. The study cases could be selected from women in selected zip codes who were pregnant and gave birth to preterm infants. Controls could be selected from the same population who gave birth to normal term infants. Exact levels of exposures could be obtained. The mother's daily exposures could be monitored monthly with questionnaire, as well as with actual air sampling data. Air sampling data should be obtained at the mother's homes and at their place of work or any other frequented locations. Confounders could be monitored and better controlled for. Some potential confounding variable that should be monitored for include alcohol use, tobacco use, type of work, and time away from home. The sample size could be much smaller than the 97,518 women who were included in this study. The timeframe to complete this study would be 1 to 2 years, which would be sufficient to compile data from several full term pregnancies. Biological monitoring would be a potential important factor in this study to suggest causation. Blood samples, cord blood, DNA samples, or interval ultrasounds could be performed to monitor any changes in the size of the fetus or in various makers in the mother's blood. Some markers could include hormone levels, white blood cell counts, or other hemopoetic indicators. Late in the pregnancy the possibility for an amniocentesis could be entertained as it would pose less risk to the fetus and could gather potentially 
revealing data about the fetuses' genetics. Genetic susceptibility to air pollution causing babies to be born preterm could have great implications on public policy and EPA standards.

As these air pollutants continue to be a part of our daily life, the effects and pathophysiology should be made clear as the outcomes can have long lasting effects on society and our children. They can lead to adult-onset diseases, such as HTN, DM II, ischemic heart disease, or decreased brain growth. Some studies indicate that prenatal hazards that restrict fetal growth may be associated with small but measurable delays in motor and social development through childhood and reduced cognitive development (Bacharach \& Baumeister 1998; Hack et al., 1991; Hediger et al.,2002). An association between birth size and future development of adult-onset diseases, such as type 2 diabetes and coronary artery disease has also been demonstrated (Godfrey \& Barker, 2001; Phillips et al., 2000). Growth retardation, intellectual impairment, and poor health outcomes can follow the child into adulthood and significantly decrease productivity in society with potential for lifelong dependence on disability or accommodations both in school and in the workplace. If a mother is exposed to these hazards, they can affect her health and the health of her baby. Society may bear the burden in either medical or disability cost. Pollution can impact working and mothers at home. Mothers and their babies are a vulnerable population who are more susceptible to lower levels of pollution. These air pollutants can possibly have long-term effects on their children. Implantation of laws and regulations, warning system, or more strict EPA standards may be needed to adequately control the cost to our society and the environment. 


\section{REFERANCES}

Alexander, G. R., \& Allen, M. C. (1996). Conceptualization, measurement, and the use of gestational age in clinical and public health practice. Journal of Perinatology, 16, $53-59$.

Alexander, G. R., Kogan, M., Martin, J., \& Papiernik, E. (1998). What are the fetal growth patterns of singletons, twins, and triplets in the United States? Clinical Obstetrics and Gynecology, 41, 114-125.

Bacharach VR, Baumeister AA et.a. (1998) . Effects of maternal intelligence, marital status, income, and home environment on cognitive development of low birth weight infants. J Pediatr Psychol.;23:197-205

Ballester, F., et al.,(2010) Air pollution exposure during pregnancy and reduced birth size: a prospective birth cohort study in Valencia, Spain. Environ Health. 9: p. 6.

Bobak, M. et.al., (2000). Outdoor air pollution, low birth weight, and prematurity. Environ. Health Perspect. 108, 173-176. 
Bobak, M., Leon, D.A., (1999). Pregnancy outcomes and outdoor air pollution: an ecological study in districts of the Czech Republic1986-8. Occup. Environ. Med. $56,539-543$.

Denmark K. Copenhagen, (2007) Estimation of the benchmark dose by structural equation models. University of Southern Denmark. Biostatistics 8, 4, pp. 675-688

Dejmek, J., Selevan, S.G., Benes, I., Solansky, I., Sram, R.J.,( 1999).Fetal growth and maternal exposure to particulate matter during pregnancy. Environ. Health Perspect. 107, 475-480.

EPA website retrieved from www.epa.gov/air/airpolutants.html

Goings SA, et.al.(1989) Effect of nitrogen dioxide exposure on susceptibility to influenza A virus infection in healthy adults. Center for Immunization Research, American Respiratory Disease. May 139(5) :1075-81

Godfrey KM, Barker DJ.et.al. (2001) Fetal programming and adult health. Public Health Nutrition.;4:611-624.

Gouveia, N., Bremner, S. A., \& Novaes, H. M. (2004). Association between ambient air pollution and birth weight in Sao Paulo, Brazil. Journal of Epidemiology and Community Health, 58(1), 11-17. 
Ha, E.H., Hong, Y.C., Lee, B.E., Woo, B.H., Schwartz, J., Christiani, D.C.,( 2001). Is air pollution a risk factor for low birth weight in Seoul? Epidemiology 12, 643-648.

Hack M, Breslau N, Weissman B, Aram D, Klein N, Borawski E. (1991) Effect of very low birth weight and subnormal head size on cognitive ability at school age. New England Journal of Medicine.;325:231-237.

Hansen, C.A., et al., (2009) Ambient air pollution and birth defects in Brisbane, Australia. PLoS One,. 4(4): p. e5408.

Hediger ML, Overpeck MD, Ruan WJ, Troedle JF (2002). Birthweight and gestational age effects on motor and social development. Pediatric Perinatal Epidemiology ;16: 33-46.

Jedrychowski, W., et al., (2004) Estimated risk for altered fetal growth resulting from exposure to fine particles during pregnancy: an epidemiologic prospective cohort study in Poland. Environmental Health Perspective,. 112(14): p. 1398-402.

Kahn, E. B., Berg, C. J., \& Callaghan, W. M. (2009). Cesarean delivery among women with low-risk pregnancies: A comparison of birth certificates and hospital discharge data. Obstetrics and Gynecology, 113(1), 33-40. 
Landgren, O. et.al.,( 1996). Environmental pollution and delivery outcomes in Southern Sweden : a study with central registries. ACTA Pediatrics. 85, 1361-1364

Lee, B.E., et al., (2003) Exposure to air pollution during different gestational phases contributes to risks of low birth weight. Human Reproduction, 2003. 18(3): p. $638-43$.

Lydon-Rochelle, M. T., Holt, V. L., Nelson, J. C., Cárdenas, V., Gardella, C., Easterling, T. R., et al. (2005). Accuracy of reporting maternal in-hospital diagnoses and intrapartum procedures in Washington State linked birth records. Pediatric and Perinatal Epidemiology, 19, 460

Maisonet, M., Bush, T.J., Correa, A., Jaakkola, J.K., (2001). Relation between ambient air pollution and low birth weight in the northeastern United States. Environ. Health Perspective. 109, 351-356.

Mannes, T., et al.,(2005) Impact of ambient air pollution on birth weight in Sydney, Australia. Occupational Environmental Medicine. 62(8): p. 524-30.

Moore, S.G., Living with the Earth. Third Edition. NewYork, P.401-457

Parker JD, Woodruff TJ, Basu R, Schoendorf KC, (2005). Air Pollution and birth weight among term infants in California. Pediatrics. Jan;115(1):121-8. 
Ren, C., S. Melly, and J. Schwartz. (2010) Modifiers of short-term effects of ozone on mortality in eastern Massachusetts--a case-crossover analysis at individual level. Environmental Health. 9: p. 3.

Rich, D. Q., Demissie, K., Lu, S. E., Kamat, L., Wartenberg, L., \& Rhoads, G. G. (2009). Ambient air pollutant concentrations during pregnancy and the risk of fetal growth restriction. Journal of Epidemiology and Community Health, 63(6), 488496

Ritz etal . (1998) Effect of Air Pollution on Preterm Birth Among Children Born in Southern California Between 1989 and 1993. Journal Of Environmental Health, 47(7), 328-334.

Salam, M.T., et al., (2005) Birth outcomes and prenatal exposure to ozone, carbon monoxide, and particulate matter: results from the Children's Health Study. Environ Health Perspective. 113(11): p. 1638-44.

Salihu HM, Ghaji N, Mbah AK, Alio AP, August EM, Boubakari I. (2011) Particulate Pollutants and Racial/Ethnic Disparity in Feto-Infant Morbidity Outcomes. Matern Child Health J. 2011 Aug 12. (NL)

Suwanwaiphatthana, W., K. Ruangdej, and A. Turner-Henson, (2010) Outdoor air pollution and children's health. Pediatric Nursing, 36(1): p. 25-32. 
Taffel, S., Johnson, D., \& Heuser, R. (1982). A method of imputing length of gestation on birth certificates. Vital and Health Statistics, 93.

Wang, X., Ding, H., Ryan, L., Xu, X.,( 1997). Association between air pollution and low birth weight: a community-based study. Environ. Health Perspective. 105, 514520.

WHO website retrieved from www.who.int/topics/pregnancy/en/

Woodruff, T.J., J. Grillo, and K.C. Schoendorf, (1997) The relationship between selected causes of postneonatal infant mortality and particulate air pollution in the United States. Environ Health Perspective, 105(6): p. 608-12. 


\section{ABOUT THE AUTHOR}

Maria B. Mainolfi, MD

Title: USF Occupational and Environmental Resident

Institution: University of South Florida, College of Public Health

Address: 13201 Bruce B. Downs Blvd., MDC 56, Tampa, FL 33612

Email: mmainolf@health.usf.edu 